CENTRO UNIVERSITÁRIO FEI

ANDRÉ LUIZ TEIXEIRA

\title{
RELAÇÃO ENTRE OS NÍVEIS DE MATURIDADE DA MELHORIA CONTÍNUA E OS ESTÁGIOS EVOLUTIVOS DA COMPETITIVIDADE EM OPERAÇÕES DE SERVIÇOS HOSPITALARES
}


ANDRÉ LUIZ TEIXEIRA

\section{RELAÇÃO ENTRE OS NÍVEIS DE MATURIDADE DA MELHORIA CONTÍNUA E OS ESTÁGIOS EVOLUTIVOS DA COMPETITIVIDADE EM OPERAÇÕES DE SERVIÇOS HOSPITALARES}

Dissertação de Mestrado apresentada ao Centro Universitário FEI para obtenção do título de Mestre em Engenharia Mecânica, área de concentração Produção, com a orientação do Prof. Dr. Dário Henrique Alliprandini

São Bernardo do Campo 
Teixeira, André Luiz.

Relação entre os níveis de maturidade da melhoria contínua e os estágios evolutivos da competitividade em operações de serviços hospitalares / André Luiz Teixeira. São Bernardo do Campo, 2017. 62 p. : il.

Dissertação - Centro Universitário FEI.

Orientador: Prof. Dr. Dário Henrique Alliprandini.

1. Gestão de operações de serviços de saúde. 2. Competitividade em operações de serviços hospitalares. 3. Nível de Maturidade em Melhoria Contínua. 4. Operações de Serviços Hospitalares. I. Alliprandini, Dário Henrique, orient. II. Título.

Elaborada pelo sistema de geração automática de ficha catalográfica da FEI com os dados fornecidos pelo(a) autor(a). 
Título do Trabalho: Relação entre os níveis de maturidade da melhoria contínua e os estágios evolutivos da competitividade em operações de serviços hospitalares.

Área de Concentração: Produção

Orientador: Prof. Dr. Dário Henrique Alliprandini

Data da realização da defesa: 03/03/2017

\section{Avaliação da Banca Examinadora:}

São Bernardo do Campo, 03 / 03 / 2017.

\section{MEMBROS DA BANCA EXAMINADORA}

Prof. Dr. Dário Henrique Alliprandini

Ass. :

Profa. Dra. Claudia Aparecida de Mattos

Ass. :

Prof. Dr. Rodrigo Valio Dominguez Gonzalez

Ass. :

A Banca Julgadora acima-assinada atribuiu ao aluno o seguinte resultado:

APROVADO $\bigotimes \quad$ REPROVADO

\section{VERSÃO FINAL DA DISSERTAČ̃̃O}

APROVO A VERSÃO FINAL DA DISSERTAÇÃO EM QUE FORAM INCLUÍDAS AS RECOMENDAÇÕES DA BANCA EXAMINADORA
Aprovação do Coordenador do Programa de Pós-graduação

Prof. Dr. Rodrigo Magnabosco 
Dedico este trabalho a Deus, minha esposa Loreta e aos meus filhos Arthur e Lucas que motivaram eu vencer este grande desafio em minha vida. 


\section{AGRADECIMENTOS}

Ao meu orientador, Prof. Dr. Dario Henrique Alliprandini, meu eterno orientador e professor, por acompanhar-me desde minha graduação e por acreditar no meu trabalho e no meu potencial, por servir de exemplo e pela paciência e confiança, por todos os ensinamentos e pela ajuda necessária o desenvolvimento deste trabalho.

A todos os professores com quem eu convivi durante o período de meu mestrado na FEI, por compartilharem comigo suas experiências e ensinamentos que foram úteis para conclusão deste trabalho.

A todos os meus familiares que sempre me apoiaram no meu desenvolvimento e aprendizagem contínua.

Ao Centro Universitário FEI, por toda infraestrutura e disponibilidade de recursos essenciais no desenvolvimento deste trabalho e por oferecer a oportunidade de contribuir com a pesquisa acadêmica no Brasil.

As empresas participantes desta pesquisa, que sem terem aberto suas portas e me recebido não seria possível o avanço e contribuição da pesquisa acadêmica no Brasil. 
"Nossa esperança está no Senhor; ele é o nosso auxílio e a nossa proteção. Nele se alegra o nosso coração, pois confiamos no seu santo nome. Esteja sobre nós o teu amor, Senhor, como está em ti a nossa esperança".

Bíblia; Salmos 33:20-22 


\section{RESUMO}

Este trabalho trata do estudo de um modelo referencial para direcionamento de ações nas operações das organizações por estágios de evolução no contexto de atividades de melhoria contínua das operações. O modelo é conhecido por "modelo dos quatro estágios da competitividade de empresas de serviços" apresentado pelos pesquisadores Richard Chase e Robert Hayes. O modelo pode apoiar a atividade de diagnóstico da situação atual e serve de base para se estabelecer novos padrões de desempenho para uma situação futura. Para isso, o modelo apresenta seis diferentes capacidades que caracterizam os estágios e quatro dimensões para avaliação. Entretanto, uma capacidade específica não é contemplada no modelo quando se trata do contexto da melhoria contínua de processos - habilidades e comportamentos padrão da melhoria contínua. Essas habilidades e comportamentos estão relacionados aos níveis de maturidade da melhoria contínua. Dessa forma, é razoável admitir que esses níveis de maturidade podem ser relacionados aos estágios de evolução do modelo de competitividade das operações de serviços com vistas a promover a evolução nos estágios da competitividade nas operações de serviços. Assim, o objetivo deste trabalho é estudar a relação dos níveis de maturidade da melhoria contínua com as dimensões do modelo de competitividade das operações de serviços, verificando a possibilidade de relacionar as habilidades de cada nível de maturidade da melhoria contínua com os aspectos inerentes a cada estágio evolutivo. O trabalho foi desenvolvido por meio de uma pesquisa de campo pelo método de estudo de caso em empresas do segmento de atendimento médico-hospitalar que possuam práticas de melhoria contínua estruturada tanto por meio de programas como por meio de sistemas da qualidade e que possuam características em comum tais como finalistas do prêmio nacional da qualidade ou certificadas por meio de referências de sistemas da qualidade. Os principais resultados encontrados foram: identificação da existência de relação entre o estágio de competitividade em operações de serviços e o nível de maturidade da melhoria contínua; melhor compreensão dos elementos bases da melhoria contínua que deve ser comum a qualquer empresa que estejam progredindo no estágio de competitividade de operações.

Palavras-chaves: Gestão de operações de serviços de saúde. Competitividade em operações de serviços hospitalares. Nível de Maturidade em Melhoria Contínua. Operações de Serviços Hospitalares. 


\begin{abstract}
This study is related to a reference model for addressing actions in the operations of service firms by stages of evolution in the context of continuous improvement activities. The model is known as "Four stage of service firm competitiveness framework" presented by the researchers Richard Chase and Robert Hayes. The framework can support the diagnosis of a current situation and serves as the basis to set new performance standards for a future situation. For this, the framework has six different capabilities aspects that characterize the stage and four dimensions for evaluation. However, one specific capability is not included - abilities and behaviors of continuous improvement practice. These abilities and behaviors are related to the maturity levels of continuous improvement. Thus, it is reasonable to assume that these levels of maturity could be related to each evolutionary stage of the service firm competitiveness framework in order to promote the operation evolution in these stages. The objective of this project is to study the relationship of continuous improvement maturity levels with the dimensions of the competitiveness of service operations framework, verifying the possibility of linking the abilities of each maturity level of continuous improvement with the aspects inherent in each evolutionary stage. The project was developed through field research by case study method in medical-hospital segment that have practices of continuous improvement structured both through programs and through quality systems and that have characteristics in common such as national quality award finalists or certified through references of quality systems. The main results of this research were: identification of the existence of a relationship between the stage of competitiveness in service operations and the level of maturity of continuous improvement; Better understanding of the basic elements of continuous improvement that should be common to any company that is progressing at the stage of operations competitiveness.
\end{abstract}

Key Words: Health Service Operations Management. Competitiveness in Hospital Services Operations. Maturity Level in Continuous Improvement. Healthcare Service Operations. 


\section{LISTA DE ILUSTRAÇÕES}

Quadro 1 - Habilidades e comportamentos da melhoria contínua ......................................... 15

Quadro 2 - Estágios de evolução da melhoria contínua....................................................... 18

Figura 1 - Modelo de Infraestrutura de melhoria contínua.................................................... 19

Quadro 3 - Áreas de decisão de infraestrutura de melhoria contínua - Objetivo, Conceitos e

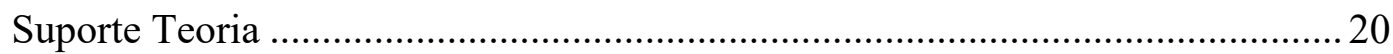

Figura 2 - Elementos da gestão de operações de serviços...............................22

Quadro 4 - Modelo 4-Estágios da competitividade em operações de empresas de serviços...24

Figura 3 - Paradigma da Estratégia de Manufatura aplicado em Serviços.....................25

Figura 4 -. Ilustração Modelo Teórico...................................................27

Figura 5 - Modelo Teórico - Constructos ou Fatores ..................................................... 28

Quadro 5 - Objeto de Estudo - Amostra hospitais brasileiros com acreditação ONA ............ 31

Figura 6 - Visão geral da metodologia de desenvolvimento da pesquisa................................ 31

Quadro 6 - Quadro Resumo Estudo de Casos............................................................................. 32

Quadro 7 - Classificação dos estudos de casos nos estágios de maturidade de melhoria contínua.......................................................... 33

Quadro 8 - Sistematização aspectos gerais da melhoria contínua nas empresas estudas......36

Quadro 9 - Classificação das empresas analisadas nos estágios de competitividade de Operações de Serviços................................................ 40

Quadro 10 - Comparativos entre os estágios de competividade para empresas analisadas... 42

Quadro 11 - Sistematização aspectos gerais da competitividade em operações de serviços... 42

Figura 7 - Ilustração da relação entre nível de maturidade da melhoria contínua e competividade em operações de serviços................................ 50

Quadro 12 - Síntese das melhores práticas encontradas nos casos analisados............... 51

Figura 8 - Matriz relacionamento nível de maturidade da melhoria contínua vs estágio de competitividade de operações de serviços................................... 53 
1 INTRODUÇÃO

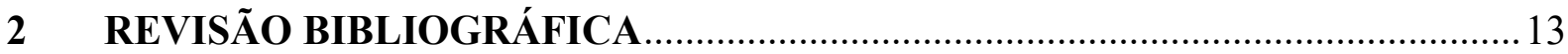

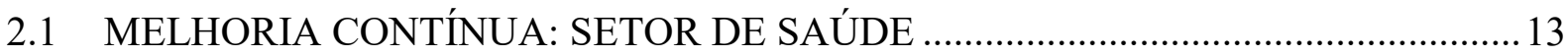

2.2 MELHORIA CONTÍNUA: CONCEITOS E NÍVEIS DE MATURIDADE ................. 14

2.3 MELHORIA CONTÍNUA: ELEMENTOS DE INFRAESTRUTURA DE MELHORIA

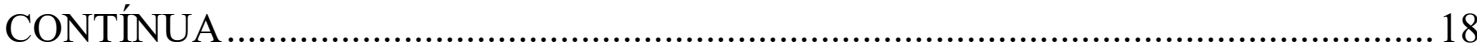

2.4 MODELO DOS ESTÁGIOS EVOLUTIVOS PARA COMPETITIVIDADE DAS OPERAÇÕES DE SERVIÇOS

2.5 RELACIONANDO MODELO 4-ESTÁGIO DE COMPETITIVIDADE EM OPERAÇÕES DE SERVIÇOS E MODELO DE MATURIDADE EM MELHORIA CONTÍNUA 26

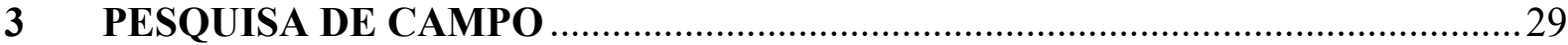

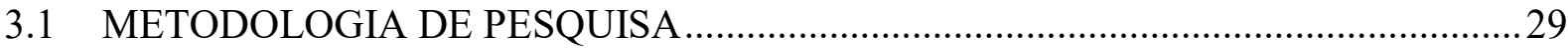

3.2 DESCRIÇÃO DAS OBSERVAÇÕES E RESULTADOS …............................................. 32

3.2.1 Maturidade da Melhoria Contínua nos casos analisados ..........................................33

3.2.2 Estágio de competitividade em operações de serviços nos casos analisados ............ 39

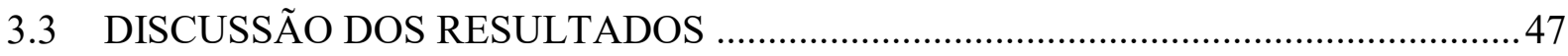

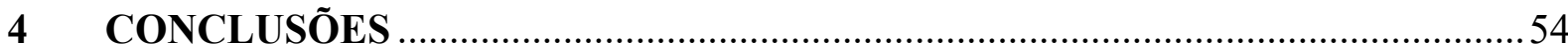

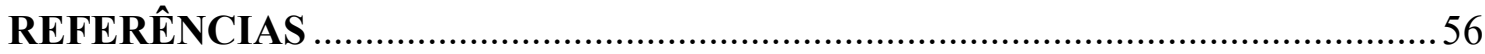




\section{INTRODUÇÃO}

Os sistemas de produção tanto de empresas manufatureiras como de empresas de serviço são estruturas dinâmicas nas organizações, pois devem se adaptar continuamente às mudanças e inovações tanto do produto quanto das tecnologias de processo envolvidas. Essa dinâmica é importante pois está associada à competitividade da empresa. Nesse contexto, entender como as práticas gerenciais e operacionais do sistema produtivo de uma empresa podem caracterizar seu posicionamento em estágios evolutivos de sua competitividade é relevante, pois pode facilitar o estabelecimento de esforços para melhorias do sistema de produção, além de inovações, mudanças e adequações.

As melhorias de um sistema de produção podem ser realizadas com base na aplicação de ferramentas de melhoria contínua, sendo razoável considerar que elas estejam relacionadas à evolução de habilidades e práticas de melhoria que levam a níveis de maturidade de sua aplicação (BESSANT; CAFFYN; GALLAGHER, 2001).

De fato, há evidências que indicam que os programas de melhoria contínua são recursos eficazes para alcançar fatores de desempenho mais elevados em qualidade e outros objetivos, incluindo inovação, além de apoiar o desenvolvimento de competências e facilitar a consolidação de um ambiente propício a mudanças organizacionais (PRAJOGO; SOHAL, 2001; COLE, 2001; PERDOMO-ORTIZ; GONZÁLEZ-BENITO; GALENDE, 2006; ZEHIR; SADIKOGLU, 2010).

A prática da melhoria contínua pode ser realizada em qualquer ambiente organizacional e as operações de empresas de serviços podem ser consideradas como objetos de estudos tanto devido a sua importância no contexto econômico como pela sua necessidade de buscar melhor desempenho em suas operações.

Segundo Chase e Hayes (1991), empresas de serviços podem estruturar suas operações usando como referência um modelo de estágios evolutivos de competitividade e aplicar conceitos e estratégias consagradas na área de manufatura como foco e integração em suas operações, visando a evolução das operações da empresa nos estágios.

Embora seja razoável admitir que uma maior maturidade na prática de melhoria contínua possa gerar maior contribuição na competividade de uma operação de serviços, pouco ou quase nenhuma discussão tem sido realizada com o objetivo de entender a relação entre o nível de competividade de operações de serviços e maturidade na utilização de práticas de melhoria contínua, pelo contrário, grande parte das publicações é encontrada com objetivo de avaliar estas capacidades de gestão em separado, ou seja, competividade de operações de 
serviços (CHASE; HAYES, 1991) e maturidade na prática de melhoria contínua (BESSANT; CAFFYN; GALLAGHER, 2001; CAFFYN, 1999; ANAND et al, 2009).

A justificativa desta pesquisa está baseada nessa perspectiva. O interesse do trabalho está no estudo da relação entre os níveis de maturidade da melhoria contínua e as dimensões de um modelo referencial de estágios evolutivos da competitividade das operações em empresas de serviços. Dessa forma, pode-se considerar que aspectos inerentes a cada nível do modelo de maturidade da melhoria contínua devem estar associados a diferentes estágios evolutivos do modelo referencial. Preliminarmente, pode-se identificar que as dimensões que caracterizam os estágios evolutivos das operações de serviço não mostram nenhuma relação com práticas de melhoria de processos, o que despertou o foco da proposta do presente trabalho nessa lacuna. Assim, pode-se esperar que os resultados colaborem ou para a inclusão da dimensão "práticas/maturidade da melhoria contínua" na estrutura do modelo, ou para a indicação da aplicação da melhoria contínua como um dos facilitadores para a mudança de estágio em algumas das dimensões previstas no modelo.

Assim, o objetivo deste trabalho é estudar a relação entre os níveis de maturidade da melhoria contínua e as dimensões do modelo dos estágios de competitividade das operações de serviços hospitalares, verificando a possibilidade de se associar as habilidades de cada nível de maturidade da melhoria contínua com os aspectos inerentes a cada estágio evolutivo do modelo dos estágios. Dessa forma, pode-se construir uma questão de pesquisa para este trabalho: "Como as características dos níveis de maturidade da melhoria contínua podem ser relacionadas a cada dimensão e a cada estágio do modelo dos estágios evolutivos da competitividade das operações de serviços hospitalares”?

Para responder essa pergunta, o trabalho foi desenvolvido por meio de uma pesquisa de campo do tipo estudo de caso, com características exploratória e qualitativa, realizada em três hospitais com práticas de melhoria contínua implementadas e com visão competitiva no setor.

A motivação da realização deste trabalho em operações de serviços hospitalares ocorre da oportunidade de explorar a relação entre a prática de melhoria contínua e a competividade de operações de serviços em um setor que se encontra relativamente nos estágios iniciais da melhoria contínua. A melhoria contínua vista como uma estratégia de negócios pode permitir que o setor de saúde entregue um serviço de alta classe aos pacientes ao tratar de questões centrais dos cuidados de saúde e melhoria de vida dos pacientes (TANER; SEZEN; ANTONY, 2007). 
Para melhor compreensão da aplicação deste tema nas literaturas acadêmicas, realizouse uma pesquisa utilizando como base de dados a ISI - Web of Knowledge (Web of Science) e SciVerse (Scopus), por se tratar de bases de grande referência acadêmica. A string de busca utilizada foi "continuous improvement" resultando em 55.140 publicações das mais diversas áreas temáticas.

Em seguida foram aplicados dois filtros de seleção. O primeiro filtro foi relacionado com a aplicação da melhoria contínua no setor de saúde hospitalar, para isto utilizou-se como string de filtro "healthcare" ou "hospital" resultando em 4.487 publicações. O segundo filtro foi relacionado ao tipo de documento, no qual foi selecionado somente artigos. Após aplicação deste segundo filtro, a amostra foi reduzida para 3.588 artigos, que foram submetidos ao filtro de seleção, que compreendeu a aplicação do critério de inclusão por meio da leitura do título, do resumo e palavras-chave, resultando em uma amostra final de 153 artigos.

Em relação ao total de artigos encontrados, aproximadamente $85 \%$ dos artigos foram publicados nos últimos 10 anos (2006 - 2016), 80\% dos artigos publicados concentram-se em 54 fontes diferentes de publicações (total de 87 fontes de publicações do tipo "Journal”) e 48\% dos artigos publicados concentram-se em 31 diferentes autores (total de 160 diferentes autores). Se considerarmos as áreas acadêmicas interessadas por este assunto, temos que que $83 \%$ das publicações foram publicadas pelas áreas de Engenharia (32\%), Administração de Empresas (21\%), Medicina (15) e Ciências (15\%).

Com isto, é possível afirmar que o tema deste trabalho é um tema recente com amplo interesse de diferentes áreas acadêmicas e explorado por diversos fontes de publicação, reforçando assim a importância deste trabalho para contribuição da pesquisa acadêmica sobre o assunto da melhoria continua em operações hospitalares.

Este exemplar de dissertação está dividido em cinco capítulos, incluindo esta introdução e as referências bibliográficas.

O primeiro capítulo - Introdução - apresenta o contexto e motivação acadêmica na qual esta pesquisa está inserida, além de apresentar os elementos sobre a questão de pesquisa, objetivo e uma visão geral do método de investigação utilizado.

A revisão bibliográfica está no segundo capítulo. Nele apresentam-se uma breve revisão acerca do arcabouço teórico que suporta o desenvolvimento desta pesquisa, tais como melhoria contínua no setor de saúde, melhoria contínua e seus conceitos e níveis de maturidade; modelo dos estágios evolutivos para competitividade das operações de serviço; algumas evidências sobre a melhoria contínua como abordagem potencial para facilitar a evolução das operações de uma empresa de serviço. Ele é finalizado com a apresentação de uma síntese do 
relacionamento do modelo dos quatro estágios da competitividade das operações de serviços e o modelo de maturidade da melhoria contínua.

O capítulo 3 é dedicado à pesquisa de campo, incluindo a metodologia adotada, descrição do objeto de estudo, relato das observações encontradas e sua análise.

Por fim, o capítulo 4 traz as conclusões e considerações finais do trabalho. 


\section{REVISÃO BIBLIOGRÁFICA}

Este capítulo trata da revisão bibliográfica realizada. São apresentados aplicação na melhoria contínua no setor de saúde, os principais conceitos sobre melhoria contínua e seu modelo dos níveis de maturidade, o modelo dos estágios evolutivos para competitividade das operações de serviço, bem como algumas evidências sobre a melhoria contínua como abordagem potencial para facilitar a evolução das operações de uma empresa de serviço.

\subsection{MELHORIA CONTÍNUA: SETOR DE SAÚDE}

A aplicação de práticas de gerenciamento para melhorar a eficiência e qualidade na área da saúde ainda é recente. Embora esta teve seu início na última década, é cada vez mais crescente o interesse pelo tema, contribuindo assim para surgimento de novos modelos de implantação (TRISOLINI, 2002). Este interesse justifica a demanda existente no setor para muito que ainda pode ser feito para melhorar a performance desta indústria que ainda é marcada pela ineficiência no atendimento aos pacientes e no uso de recursos, onde diversos autores salientam para o expressivo número de casos de sucesso na implementação de programas de gestão, em especial de gestão da qualidade em organizações do setor de saúde (HEUVEL et al, 2005; TRISOLINI, 2002; STEAD; LEONARD, 1995).

Se por um lado, a implantação de programas de melhoria contínua no setor de saúde, onde muitas vezes é vista através da implementação de programas Seis Sigma, ainda é muito incipiente, tendo sua linguagem ainda focada em resultados financeiros o que gera alguma resistência em sua adoção no setor. Por outro lado, algumas organizações de forma pioneira vêm implementando o programa e obtendo bons resultados (HEUVEL et al,2005).

Ao longo da última década, o interesse das instituições de saúde em se tornarem mais eficientes tem sido impulsionado em grande parte por preocupações financeiras. As organizações de saúde atuais são sistemas cada vez mais dinâmicos complexos, estando cada vez mais focadas em melhorar a qualidade dos cuidados ao paciente e cumprir com diretrizes locais e globais cada vez mais rigorosas, tornando, assim, cada vez mais necessário reexaminar seus processos sob a ótica da melhoria contínua tendo como grande foco i) melhoria nos resultados clínicos, ii) aumento da satisfação de seus clientes e iii) eficiência na execução de seus processos (TANER; SEZEN; ANTONY, 2007). 
Se considerarmos a prática de Lean Manufacturing no setor de saúde como uma das principais formas de adoção da prática de melhoria contínua neste mesmo setor, é possível considerar que as organizações de saúde estão em uma fase equivalente ao final dos anos 1980 e início dos anos 90 na indústria automotiva e ainda estão a abraçar a metodologia Lean Thinking de forma mais ampla em todo o sistema de saúde (RADNOR; HOLWEG; WARING, 2012).

Neste contexto, segundo Jackson (1999), não há dúvida de que a utilização dos modelos de auto avaliação é vital para alcançar uma cultura de melhoria contínua. Tendo em conta os benefícios a longo prazo é percebido que a partir do uso de modelos de auto avaliação é um caminho certo para a atingir a cultura de melhoria contínua e entrega de serviços com qualidade no setor de saúde.

\subsection{MELHORIA CONTÍNUA: CONCEITOS E NÍVEIS DE MATURIDADE}

As atividades de melhoria surgem como resposta a um contexto de grande dinamismo do mercado, em que há necessidade de se adaptar continuamente. O desempenho dos negócios está relacionado à capacidade de a empresa gerir seus processos e suas operações de maneira eficiente, o que pode ser alcançado por meio da aplicação efetiva das práticas de melhoria contínua (BESSANT; CAFFYN; GALAGHER, 2001).

Jha, Noori e Michela (1996) definem Melhoria Contínua como um conjunto de atividades que constituem um processo de raciocínio e intervenção que busca alcançar a melhoria de desempenho. Bhuiyan, Baghel e Wilson (2006) definem a melhoria contínua como uma cultura de melhoria sustentável, visando, por meio do envolvimento de todos os participantes da organização, eliminar desperdícios em todos os sistemas e processos organizacionais. Trata-se de todos trabalhando juntos para melhorar, com foco nas metas organizacionais e sem necessariamente grandes investimentos de capital (BESSANT; FRANCIS, 1999; BHUIYAN; BAGEL, 2005).

A capacidade de melhoria contínua pode ser entendida como um recurso-chave associado a altos níveis de envolvimento no processo de mudança por meio da contribuição de ideias de melhorias incrementais de maneira regular de uma grande parte da força de trabalho (BESSANT; CAFFYN; GILBERT, 1996). A prática de melhoria contínua representa um elemento importante para a dinâmica de uma organização, já que oferece mecanismos por meio dos quais uma grande proporção da organização torna-se envolvida no processo de inovação e aprendizado (BESSANT; FRANCIS, 1999). 
Os benefícios da melhoria contínua são diversos e bem conhecidos (JHA; NOORI; MICHELA, 1996). O envolvimento e apoio de todos os colaboradores com ações de melhoria contínua resultam em uma maior interação entre as pessoas de diversas áreas e níveis hierárquicos; a criatividade dos colaboradores promovida por meio de incentivos para gerar sugestões e novas ideias gera motivação e melhores condições de trabalho. A realização de ações de melhoria contínua promove o desenvolvimento das pessoas; o aumento da consistência e conformidade dos produtos e processos; tempos de resposta mais rápidos; e uma organização com menos desperdício (JHA; NOORI; MICHELA, 1996; BHUIYAN; BAGHEL; WILSON, 2006).

Apesar de ser um conceito simples, a melhoria contínua é difícil de ser implantada e mantida ao longo do tempo, por serem necessários aprendizado e adaptação constantes (BESSANT; CAFFYN; GILBERT, 1996). Por isso, alguns modelos para análise da evolução da melhoria contínua foram criados. São os modelos de maturidade que auxiliam a identificar qual o nível de utilização e de comprometimento da organização com comportamentos e práticas relacionados à melhoria contínua (BESSANT; CAFFYN; GILBERT, 1996; CAFFYN, 1999; BESSANT; FRANCIS, 1999; BESSANT; CAFFYN; GALLAGHER, 2001).

Para interpretar as necessidades particulares dos clientes, prever a evolução tecnológica da indústria ou selecionar e priorizar projetos existem práticas e comportamentos que descrevem "como fazemos as coisas por aquil" e que são, em geral, padrões inconscientes de comportamento (BESSANT; CAFFYN; GILBERT, 1996).

Os comportamentos bem-sucedidos, que estão baseados em crenças e valores da organização, tornam-se rotinas e transformam-se na cultura da organização, refletindo-se na estrutura organizacional, políticas e procedimentos, são habilidades de condução da melhoria contínua (CAFFYN, 1999; BESSANT; CAFFYN; GALLAGHER, 2001).

A imitação, por outras organizações, das habilidades e rotinas geradas pelas práticas é extremamente difícil: os comportamentos têm que ser desenvolvidos e estão relacionados com a aprendizagem e a criação de ativos intangíveis para a organização, aumentando a sua vantagem competitiva (CAFFYN, 1999). Uma lista das nove habilidades e de comportamentos relacionados com a melhoria contínua pode ser observada no Quadro 1. 
Quadro 1 - Habilidades e comportamentos da melhoria contínua

\begin{tabular}{|c|c|}
\hline dades & Comportamentos \\
\hline $\begin{array}{l}\text { "Entendendo a melhoria } \\
\text { contínua"- a capacidade } \\
\text { de articular os valores } \\
\text { básicos da melhoria } \\
\text { contínua. }\end{array}$ & $\begin{array}{l}\text { Pessoas de todos os níveis demonstram uma crença na melhoria contínua; todos } \\
\text { buscam contribuir, participando ativamente na realização e reconhecimento das } \\
\text { melhorias incrementais; } \\
\text { Pessoas fazem uso de algum método formal para resolução de problemas; } \\
\text { Na ocorrência de algum erro, as pessoas de todos os níveis buscam razões do ocorrido } \\
\text { em vez de culpar os indivíduos envolvidos; }\end{array}$ \\
\hline $\begin{array}{l}\text { "Adquirindo } \\
\text { melhoria co } \\
\text { capacidad } \\
\text { envolvi } \\
\text { sustentado e } \\
\text { Increm }\end{array}$ & 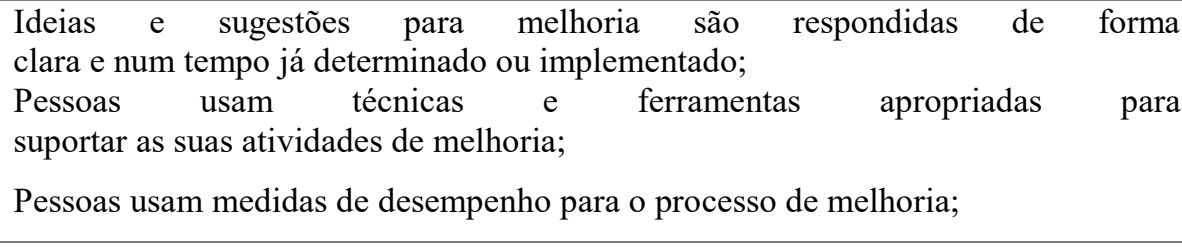 \\
\hline $\begin{array}{l}\text { "Focando a melhoria } \\
\text { contínua"- a capacidade } \\
\text { de interligar as } \\
\text { atividades de melhoria } \\
\text { contínua e os objetivos } \\
\text { estratégicos da empresa. }\end{array}$ & $\begin{array}{l}\text { Antes de começar uma investigação inicial e antes de implementar soluções, } \\
\text { indivíduos e grupos avaliam as melhorias propostas em oposição a objetivos } \\
\text { estratégicos, para assegurar consistência; } \\
\text { Todos compreendem a estratégia da empresa ou de seu departamento, } \\
\text { assim como suas metas e objetivos; } \\
\text { Indivíduos e grupos monitoram/medem os resultados de suas atividades } \\
\text { de melhoria e seus impactos na estratégia ou nos objetivos departamentais; }\end{array}$ \\
\hline $\begin{array}{l}\text { "Conduz } \\
\text { caminho"- a } \\
\text { de liderar, } \\
\text { apoiar a cr } \\
\text { manuten } \\
\text { comportam } \\
\text { melhoria ce }\end{array}$ & $\begin{array}{l}\text { S conduzem, dando o exemplo, tornando-se envolvidos ativamente no } \\
\text { nento e implementação de melhorias progressivas sistemáticas. } \\
\text { s apoiam processos de melhoria, alocando tempo, dinheiro, espaço e recursos } \\
\text { tes. } \\
\text { s apoiam a experimentação, não punindo erros, mas encorajando, através de } \\
\text { izes. }\end{array}$ \\
\hline $\begin{array}{c}\text { "Alinhando a melhoria } \\
\text { contínua"- a habilidade } \\
\text { de gerenciar } \\
\text { estrategicamente o } \\
\text { desenvolvimento do } \\
\text { sistema de melhoria } \\
\text { contínua nas estruturas } \\
\text { da organização. }\end{array}$ & $\begin{array}{l}\text { Avaliações progressivas garantem que os processos, estruturas e } \\
\text { sistemas organizacionais apoiam consistentemente e reforçam atividades de } \\
\text { melhoria. } \\
\text { Indivíduos responsáveis por processos específicos da empresa realizam revisões } \\
\text { periódicas para garantir que eles continuem compatíveis com o sistema de melhoria } \\
\text { contínua. } \\
\text { Quando uma grande mudança organizacional é planejada, } \\
\text { seu impacto potencial no sistema de melhoria organizacional é avaliado, e ajustes } \\
\text { são feitos no caso de necessidade. }\end{array}$ \\
\hline $\begin{array}{l}\text { "Compartilhamento de } \\
\text { solução de problemas"- } \\
\text { a habilidade de mover } \\
\text { as atividades de }\end{array}$ & $\begin{array}{l}\text { S e grupos estão trabalhando efetivamente através das divisões internas } \\
\text { lateral) e externas em todos os níveis. } \\
\text { ăo orientadas em relação a clientes internos e externos nas suas atividades } \\
\text { ia. }\end{array}$ \\
\hline $\begin{array}{l}\text { melhoria contínua para } \\
\text { além das fronteiras } \\
\text { organizacionais. }\end{array}$ & oria relevantes envolvem representantes de diferentes níveis \\
\hline $\begin{array}{l}\text { "melhoria contínua da } \\
\text { melhoria contínua" - a } \\
\text { capacidade de gerenciar } \\
\text { estrategicamente o } \\
\text { desenvolvimento da } \\
\text { melhoria contínua. }\end{array}$ & $\begin{array}{l}\text { Atividades e resultados de melhorias são continuamente medidos e monitorados. } \\
\text { Existe uma revisão periódica do sistema de melhoria contínua em relação à } \\
\text { organização como um todo, o que pode levar a uma maior reestruturação (loop duplo } \\
\text { de aprendizado). } \\
\text { Alta gerência disponibiliza recursos suficientes (tempo, dinheiro, pessoal) para } \\
\text { apoiar o desenvolvimento contínuo do sistema de melhoria da empresa. }\end{array}$ \\
\hline $\begin{array}{l}\text { "A organização de } \\
\text { aprendizagem" - a } \\
\text { garantia de que a } \\
\text { aprendizagem ocorra } \\
\text { seja capturada e } \\
\text { compartilhada em tod } \\
\quad \text { os níveis. }\end{array}$ & $\begin{array}{l}\text { Indivíduos e grupos de todos os níveis compartilham (tornam disponíveis) seus } \\
\text { aprendizados através de todo tipo de trabalho e experiências de melhoria. } \\
\text { Indivíduos procuram oportunidades de aprendizado/desenvolvimento } \\
\text { pessoal (por exemplo, experimentação ativa), relacionados aos objetivos de } \\
\text { aprendizado. } \\
\text { A organização articula e consolida (captura e compartilha) o aprendizado de } \\
\text { indivíduos e grupos. }\end{array}$ \\
\hline
\end{tabular}

Fonte: Bessant, Caffyn e Gallagher (2001) 
Longe de ser uma característica binária única (tem ou não tem), os comportamentos/práticas mostram que é possível identificar um padrão evolutivo de desenvolvimento da melhoria contínua (BESSANT; CAFFYN; GALAGHER, 2001). As organizações podem desenvolver os conjuntos de comportamentos em diferentes níveis e fazer uso deles, sendo alguns mais críticos do que outros em diferentes estágios do desenvolvimento da melhoria contínua (BESSANT; CAFFYN; GALAGHER, 2001; JORGENSEN; BOER; LAUGEN, 2006). Os comportamentos são genéricos, ou seja, eles se aplicam a todas as organizações e devem estar presentes em qualquer empresa que tenha o objetivo de ter a melhoria contínua implantada (CAFFYN, 1999). O nível de maturidade de implantação dessas práticas impacta no desempenho operacional (JORGENSEN; BOER; LAUGEN, 2006) e podem também impactar na inovação.

O estudo das práticas e habilidades da melhoria contínua nas organizações resultou em um modelo com diferentes níveis de maturidade da melhoria contínua (CAFFYN, 1999; BESSANT; CAFFYN; GALLAGHER, 2001). A movimentação entre os níveis representa o processo de aprendizagem (BESSANT; CAFFYN; GALLAGHER, 2001). O modelo pode ser observado no Quadro 2.

Cada estágio é chamado, pelos autores, de nível de maturidade e varia do nível 0 nenhuma atividade de melhoria contínua - ao nível 5 - estágio de capacidade total em melhoria contínua, gerando a "organização que aprende". Cada estágio prevê comportamentos e atitudes que o caracterizam. Os padrões de comportamento associados a cada nível de maturidade são também conhecidos como rotinas, que fazem parte da cultura organizacional e estão relacionados com as habilidades organizacionais da empresa (BESSANT; CAFFYN; GALLAGHER, 2001).

Embora alguns autores tem trabalhado na revisão do modelo de 5 níveis de maturidade em melhoria contínua de Bessant (2001) sugerindo uma versão de 3 diferentes níveis de maturidade (Nível 1 - Passando pelo movimento inicial, Nível 2 - Transformando e Nível 3 Parte da Cultura) como uma opção para avaliar a maturidade da melhoria contínua no setor público, a base destas propostas continuam sendo modelo clássico de Bessant (2001) reforçando a visão que a melhoria contínua é um processo evolucionário do que simplesmente uma operação binária do tipo liga/desliga (FREYER; OGDEN; ANTHONY, 2012).

A evolução da melhoria contínua não é um processo linear simples, é um processo facetado e influenciado por diversas variáveis que impactam na progressão e retração de um programa de melhoria contínua dentro de uma empresa. Além disto, não é um processo binário, mas sim com clara evidências de alternâncias entre diferentes níveis de patrocínio da alta 
administração, participação e engajamento da organização nesta jornada. Neste contexto, a aplicação do modelo de maturidade demonstra como a atividade de melhoria contínua pode ser efetivamente medida em múltiplas habilidades contribuindo assim para sua evolução dentro dos objetivos da organização (MILNER; SAVAGE, 2016).

Quadro 2 - Estágios de evolução da melhoria contínua

\begin{tabular}{|c|c|}
\hline Nível da Melhoria Contínua & Padrões de comportamento característicos \\
\hline $\begin{array}{l}\text { Nível } 1 \text { - Pré-Melhoria Contínua: } \\
\text { O interesse no conceito já foi iniciado (por } \\
\text { uma crise ou visita a outra organização etc.), } \\
\text { mas a implementação é feita de forma ad hoc. }\end{array}$ & $\begin{array}{l}\text { Os problemas são resolvidos aleatoriamente; não existe } \\
\text { nenhum esforço ou estrutura formal para melhorar a } \\
\text { organização; as soluções visam a benefícios de curto prazo; } \\
\text { não há nenhum impacto estratégico sobre os recursos humanos, } \\
\text { financeiros ou outras metas mensuráveis; gerências e áreas de } \\
\text { apoio não estão conscientes de a melhoria contínua ser um } \\
\text { processo. }\end{array}$ \\
\hline $\begin{array}{l}\text { Nível } 2 \text { - Melhoria Contínua estruturada: } \\
\text { Há um compromisso formal de construir um } \\
\text { sistema que vai desenvolver a melhoria } \\
\text { contínua por toda a organização. }\end{array}$ & $\begin{array}{l}\text { Ações de melhoria contínua são organizadas; as áreas de apoio } \\
\text { usam processos estruturados de solução de problemas; as áreas } \\
\text { de apoio participam das atividades de melhoria contínua e são } \\
\text { treinadas nas ferramentas básicas de melhoria contínua; há a } \\
\text { um sistema estruturado de gerenciamento de ideias; há a } \\
\text { introdução de um sistema de reconhecimento e recompensa; as } \\
\text { atividades de melhoria contínua estão integradas às operações } \\
\text { do dia a dia. }\end{array}$ \\
\hline $\begin{array}{l}\text { Nível } 3 \text { - Melhoria Contínua orientada } \\
\text { para metas: } \\
\text { Há o compromisso de relacionar melhoria } \\
\text { contínua com os objetivos estratégicos mais } \\
\text { abrangentes da organização. }\end{array}$ & $\begin{array}{l}\text { Os comportamentos do nível } 2 \text { mais: desdobramento formal } \\
\text { dos objetivos estratégicos; monitoramento e medição da } \\
\text { melhoria contínua em relação aos objetivos; o foco inclui a } \\
\text { solução de problemas entre áreas da empresa (processos } \\
\text { interorganizacionais) ou mesmo entre empresas. }\end{array}$ \\
\hline $\begin{array}{l}\text { Nível } 4 \text { - Melhoria Contínua proativa: } \\
\text { Há uma tentativa de dar autonomia e poder } \\
\text { aos indivíduos e grupos para gerenciar e seus } \\
\text { processos e iniciativas de melhoria. }\end{array}$ & $\begin{array}{l}\text { Todos os comportamentos dos níveis } 2 \text { e } 3 \text { mais: melhoria } \\
\text { contínua desenvolvida e focada na solução proativa de } \\
\text { problemas; altos níveis de prática de experimentação e } \\
\text { aprendizagem. }\end{array}$ \\
\hline $\begin{array}{l}\text { Nível } 5 \text { - Capacidade plena em Melhoria } \\
\text { Contínua: } \\
\text { Aproxima-se do modelo das organizações de } \\
\text { aprendizagem. }\end{array}$ & $\begin{array}{l}\text { Todos os comportamentos dos níveis } 2,3 \text { e } 4 \text { mais: o } \\
\text { aprendizado organizacional ocorre de modo largamente } \\
\text { distribuído; são comuns a iniciativa de procura e solução } \\
\text { sistemática de problemas e a aquisição e compartilhamento do } \\
\text { conhecimento obtido; a experimentação ocorre de forma } \\
\text { abrangente e autônoma. }\end{array}$ \\
\hline
\end{tabular}

Fonte: Bessant, Caffyn e Gallagher (2001)

\subsection{MELHORIA CONTÍNUA: ELEMENTOS DE INFRAESTRUTURA DE MELHORIA CONTÍNUA}

Empresas que apresentam resultados excepcionais em ambientes dinâmicos, voláteis e altamente competitivos tem como fator chave de sucesso decisões feitas pela alta gestão em 3 grupos de categorias: Propósito, Processos e Pessoas (Ghoshal; Bartlett, 1994). A Figura 1 ilustra os principais elementos da infraestrutura de melhoria contínua (Anand et al, 2009). 
Decisões tomada pela gestão de uma empresa nestas 3 categorias sãos essenciais para estrutura da melhoria contínua e sua sustentabilidade na organização (Anand et al, 2009). Propósito: Decisões de infraestrutura nesta categoria cobre toda a formulação e comunicação dos objetivos organizacionais e metas de projetos de melhoria contínua. Processos: Atingir objetivos de melhoria contínua requer todo suporte organizacional para implementar as iniciativas de melhoria contínua, principalmente na adoção de um método uniforme para descoberta e execução de melhoria contínua. Pessoas: Treinamento e motivação adequada dos colaboradores são necessárias para promover a melhoria contínua e permitir engajamento das diversas áreas e pessoas.

Figura 1. Modelo de Infraestrutura de melhoria contínua

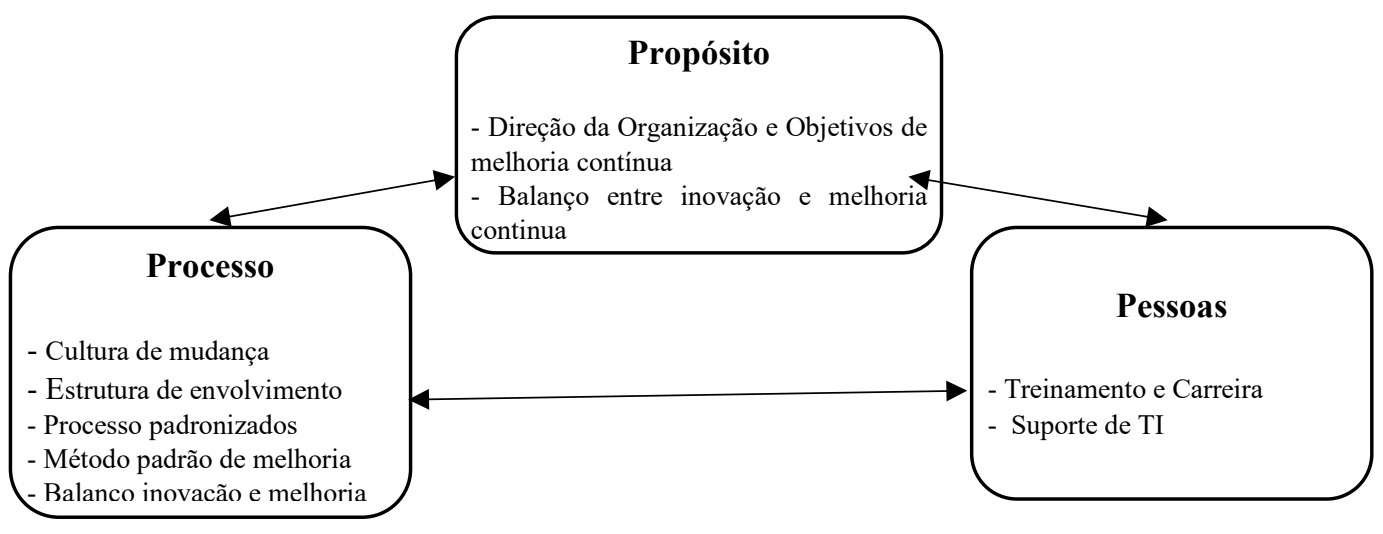

Fonte: Anand et al (2009)

O quadro 3 apresenta uma proposta de áreas de decisões relacionadas às três categorias de infraestrutura da melhoria contínua juntamente com as principais fontes de teoria que suporta cada área de decisão. 
Quadro 3. Áreas de decisão de infraestrutura de melhoria contínua - Objetivo, Conceitos e Suporte Teoria

\begin{tabular}{|c|c|c|}
\hline $\begin{array}{l}\text { Área de Decisão } \\
\text { Infraestrutura }\end{array}$ & Objetivo & Conceito e Suporte da Teoria \\
\hline $\begin{array}{l}\text { Propósito } \\
\text { Direção da Organização } \\
\text { e Objetivos de melhoria } \\
\text { contínua }\end{array}$ & $\begin{array}{l}\text { Determinar objetivos de negócio enquanto } \\
\text { mantem visão estratégica unificada } \\
\text { Facilitar participação dos níveis gerenciais } \\
\text { na formulação e implementação da } \\
\text { estratégia } \\
\text { Assegurar alinhamento do objetivo do } \\
\text { projeto com objetivos estratégicos; definir } \\
\text { e validar metas e resultados } \\
\text { Manter foco das iniciativas de melhoria } \\
\text { contínua }\end{array}$ & $\begin{array}{l}\text { Integração dos Níveis: Forrester } \\
\text { (2000a), Jelinek (1979), Linderman } \\
\text { et al. (2003) e Nonaka (1988) } \\
\text { Formulação da Estratégia Integrada: } \\
\text { Hart (1992), Beer et al (2005) e } \\
\text { Lyles (1981) } \\
\text { Aprendizagem baseada em equipe: } \\
\text { Iman (1986) e Evans (2004) }\end{array}$ \\
\hline $\begin{array}{l}\text { Balanço entre inovação e } \\
\text { melhoria contínua }\end{array}$ & $\begin{array}{l}\text { Incorporar estabilidade e objetivos de } \\
\text { mudança com melhoria de processos e } \\
\text { projetos de desenho de novos processos }\end{array}$ & $\begin{array}{l}\text { Ambidestria: Crossan and Berdrow } \\
\text { (2003), Gibson e Birkinshaw (2004), } \\
\text { Jansen et al (2006), Sitkin et al } \\
\text { (1994) e Spear e Bowen (1999) }\end{array}$ \\
\hline $\begin{array}{l}\text { Processo } \\
\text { Cultura de constante } \\
\text { mudança }\end{array}$ & $\begin{array}{l}\text { Instituir práticas e estruturas de execução } \\
\text { baseada em propósitos } \\
\text { Encorajar a busca proativa de } \\
\text { oportunidades e riscos } \\
\begin{array}{l}\text { Preparar funcionários para mudança } \\
\text { constante e reorientação }\end{array}\end{array}$ & $\begin{array}{l}\text { Varredura ambiental: Cohen et al } \\
\text { (1972), Crossan e Berdrow (12003) } \\
\text { e Elenkov (1997) } \\
\text { Aprendizagem em duplo loop: } \\
\text { Argyris e Schön (1978), Barret } \\
\text { (1995) e Sitkin et al (1994) }\end{array}$ \\
\hline Estrutura de participação & $\begin{array}{l}\text { Evitar baixa otimização da performance } \\
\text { organizacional }\end{array}$ & $\begin{array}{l}\text { Estrutura organizacionais para } \\
\text { ambientes dinâmicos: Delbridge e } \\
\text { Barton (2002), Joyce et al (1997), } \\
\text { Kogut e Zander (1992) e Mohrman } \\
\text { et al (2002) } \\
\text { Sistemas de aprendizagem: Ackoff } \\
\text { (1994) e Senge (1990) }\end{array}$ \\
\hline Processo Padronizado & $\begin{array}{l}\text { Promover mensuração e comparação de } \\
\text { projetos de melhoria }\end{array}$ & $\begin{array}{l}\text { Gestão Científica: Adler e Cole } \\
\text { (1993), MacDuffle (1997), Spear e } \\
\text { Browen (1999) e Taylor e Wright } \\
\text { (2006) } \\
\text { Experimentação Científica: } \\
\text { Forrester (2000b), Garvin (1993a) e } \\
\text { Spear e Bowej (1999). }\end{array}$ \\
\hline $\begin{array}{l}\text { Pessoas } \\
\text { Treinamento e trilhas de } \\
\text { carreira }\end{array}$ & $\begin{array}{l}\text { Investir recurso na direção de atingir um } \\
\text { objetivo } \\
\text { Permitir participação em projetos de } \\
\text { melhoria contínua } \\
\text { Atualização do corpo de conhecimento e } \\
\text { prover treinamento quando apropriado } \\
\text { Esclarecer estrutura de reporte e trilhas de } \\
\text { desenvolvimento pessoal }\end{array}$ & $\begin{array}{l}\text { Clima de participação: Bowen e } \\
\text { Lawler (1992) e Gowen et al (2006) } \\
\text { Gestão do Conhecimento: Hatch e } \\
\text { Dyer (2004); Wright e Snell (1998) } \\
\text { Práticas administrativas: Dyer e } \\
\text { Ricksens (2005) }\end{array}$ \\
\hline Suporte IT & $\begin{array}{l}\text { Suportar necessidades de medição e } \\
\text { promover repositório para reporte dos } \\
\text { projetos }\end{array}$ & $\begin{array}{l}\text { Processamento da Informação: } \\
\text { Bendoly e Swink (2007), Dasenport } \\
\text { (2006) e Garwin (1993a) }\end{array}$ \\
\hline
\end{tabular}

Fonte: Anand et al (2009) 


\subsection{MODELO DOS ESTÁGIOS EVOLUTIVOS PARA COMPETITIVIDADE DAS OPERAÇÕES DE SERVIÇOS}

Segundo Hayes e Wheelwright (1984), o papel funcional de uma operação pode ser classificado entre um de três tipos; ele pode funcionar de forma neutra ou de apoio da estratégia de negócios ou algo que impulsiona a estratégia de negócios. Este modelo foi o precursor ao modelo proposto por Chase e Hayes (1991) para a gestão de operações de serviços onde o desenvolvimento desta capacidade estratégica é conseguido através da progressão sistemática, a partir de um tipo de papel importante para o outro, ao longo de uma série contínua de capacidades de operações (LILLIS; SWEENEY, 2012).

O modelo de quatro estágios dos papéis estratégicos de operações de Hayes e Wheelwright (1984) alcançou status de clássico na literatura (SOWER; MOTWANI; SAVOIE, 1997) e tem sido utilizado, desde então, como base para muitos estudos sobre estratégia de operações (SWAMIDASS; DARLOW,2001), e contínua a estar presente nos mais diversos estudos sobre operações de manufatura e serviços (HALLGREN; OLHAGER, 2006).

Ao longo dos séculos, atividades de serviços têm desenvolvido a partir da basedoméstica, através da educação e sistemas de bem-estar familiar para o mais complexo sistemas de governo local e nacional como transporte e serviços financeiros que existem hoje (JOHNSTON, 1994).

Uma das razões para esse imperativo é, em parte, o imperativo estratégico. É possível reconhecer ao longo do tempo de que o serviço, como as mercadorias são entregues ao cliente e como o cliente é tratado, possibilita a muitas organizações criar uma vantagem competitiva (CHASE; ERIKSON, 1988; MARTIN; HORNE, 1992).

Segundo Chase e Hayes (1991), empresas de serviços podem estruturar suas operações de acordo com um modelo referencial de quatro estágios de competitividade e aplicar conceitos e estratégias consagradas na área de manufatura como foco e integração em suas operações, visando a evolução das operações da empresa nos estágios.

Empresas de serviços, especialmente em operações e serviços, são melhor compreendidas segundo três elementos da gestão de serviços: visão estratégica de serviços, níveis de serviços e funções de operações (Figura 2). 
Figura 2 - Elementos da gestão de operações de serviços

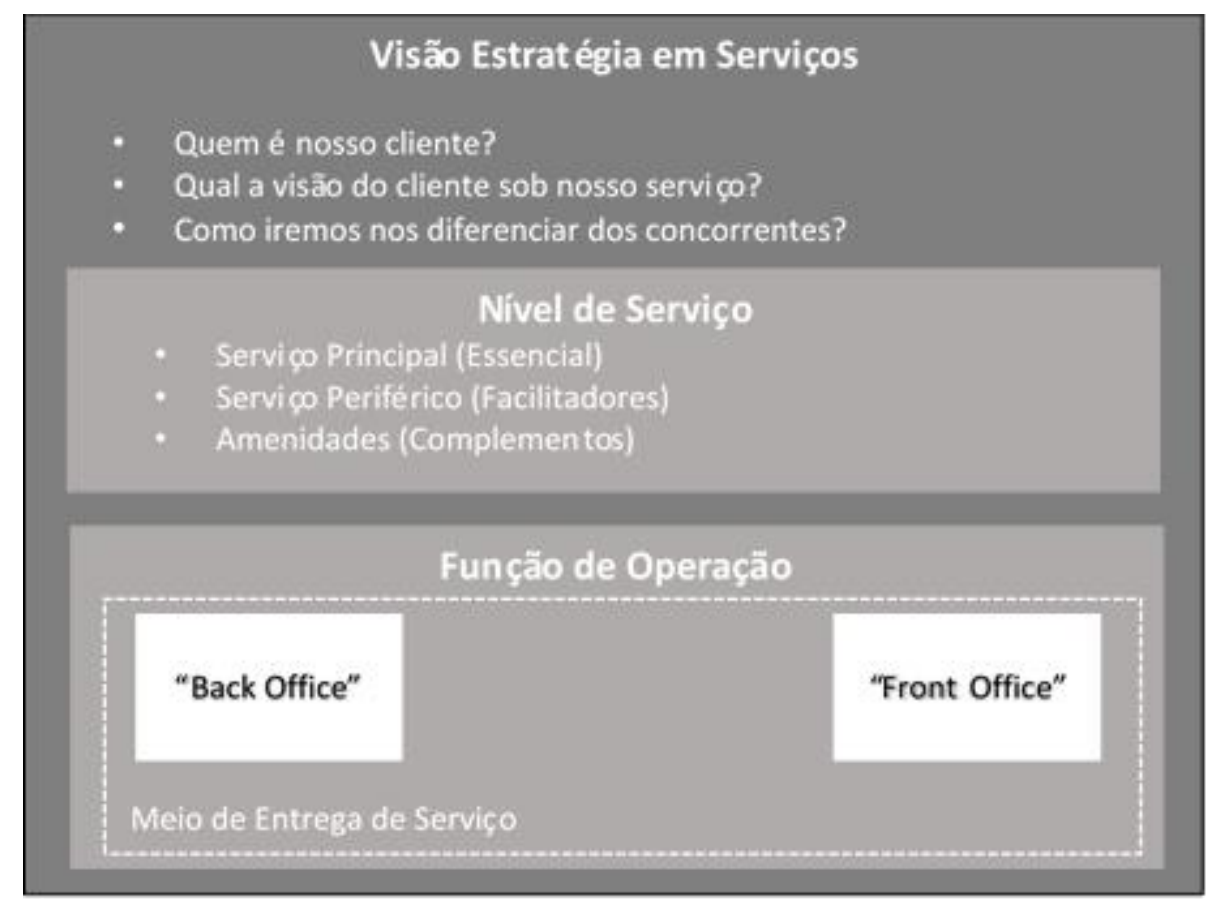

Fonte: Chase e Hayes, 1991

O elemento "visão estratégica de serviços" consiste no plano lógico e organizado para a implantação de novo negócio e ideias, visando responder basicamente as perguntas "quem é nosso cliente?" e "qual a visão do cliente sobre nosso serviço?". Adicionalmente, esta capacidade tem como foco a percepção de valor pelo cliente com objetivo de manter-se competitiva uma vez que a busca por ir além de atender necessidades, pretende-se superar as expectativas dos clientes, estabelecendo então diferenciações em relação aos concorrentes.

O elemento "Níveis de serviços" trata de aspectos que fica mais fácil de entender no contexto da qualidade dos serviços, que indicam os padrões mínimos e essenciais que um serviço deve atender, ficando para "amenidades" a definição de aditivos incorporados ao serviço entregue que pode determinar a decisão de compra de um cliente.

Por fim, o elemento "função de operações" consiste em dois conjuntos de atividades "front office" e "back office". O primeiro está em um contexto onde acontece o encontro do cliente com a organização que entrega o serviço. O segundo, trata das atividades que acontecem nos bastidores da organização, necessárias para que o serviço possa ser entregue. De fato, essa divisão auxilia na estruturação e planejamento de atividades de projeto e melhoria de sistemas de produção em serviços (GIANESI; CORRÊA, 2013).

Considerando a atividade de gestão e uma organização de serviço, independentemente da estratégia competitiva adotada, os gestores necessitam de um modelo referencial que ajudem 
no relacionamento coerente das atividades operacionais da empresa com a sua performance geral e competitiva planejada. Aí, o modelo de Chase e Hayes (1991) é uma proposta útil que permite por meio de sua aplicação, apontar o estágio atual que as diferentes dimensões das operações da empresa se encontram, bem como facilitar a definição de um desempenho superior relacionado à estratégia estabelecida pela organização, ou seja, permite traçar as metas de uma situação futura a ser buscada.

O modelo proposto é apresentado no quadro 4 e mostra a relação entre os quatro estágios evolutivos propostos pelos pesquisadores - Disponibilização do serviço (estágio 1), profissionalização (estágio 2), Diferencial competitivo (estágio 3) e Entrega de serviço classe mundial (estágio 4) - com seis dimensões relacionadas às operações - qualidade do serviço, back office, cliente, utilização de novas tecnologias, força de trabalho e gestão. Além disso, estão incluídos dois aspectos que fornecem a caracterização geral e das operações de cada estágio. Em cada cruzamento da relação, são apontadas práticas operacionais que servem de referência para avaliar a situação da empresa, bem como entender a possibilidade de mudança para estágios mais avançados.

Segundo Chase e Hayes (1991) o conceito de paradigma da estratégia de manufatura tem estado presente nas discussões acadêmica nos últimos 20 anos, mas apenas na última década ganhou relevância entre acadêmicos e praticantes. Este conceito passa pela empresa definir suas prioridades estratégicas de forma competir em uma determinada indústria e que seus produtos e serviços sejam diferenciados. O processo de paradigma da estratégia da manufatura se resume em três grandes etapas: i) definição da prioridade competitiva, ii) tomando decisões de estruturais e de infraestrutura, iii) estabelecendo disciplina que assegure que estrutura e infraestrutura se mantem consistentes com a prioridades definida. 
Quadro 4 - Modelo 4-Estágios da competitividade em operações de empresas de serviços

\begin{tabular}{|c|c|c|c|c|}
\hline $\begin{array}{l}\text { Estágios/ } \\
\text { Capacidades }\end{array}$ & $\begin{array}{l}\text { 1.Disponibilização } \\
\text { do serviço }\end{array}$ & 2. Profissionalização & $\begin{array}{l}\text { 3. Diferencial } \\
\text { competitivo } \\
\text { alcançado }\end{array}$ & $\begin{array}{l}\text { 4. Entrega de } \\
\text { serviço com classe } \\
\text { mundial }\end{array}$ \\
\hline $\begin{array}{l}\text { Qualidade de } \\
\text { serviço }\end{array}$ & $\begin{array}{l}\text { Não mede o } \\
\text { processo, geração } \\
\text { de defeitos } \\
\text { Foco no baixo } \\
\text { custo }\end{array}$ & $\begin{array}{l}\text { Opera com maior } \\
\text { formalização } \\
\text { Atende necessidade } \\
\text { básica do cliente }\end{array}$ & $\begin{array}{l}\text { Avalia a } \\
\text { expectativa do } \\
\text { cliente sob } \\
\text { diferentes } \\
\text { dimensões } \\
\text { Supera } \\
\text { expectativas }\end{array}$ & $\begin{array}{l}\text { Busca por meio de } \\
\text { programas de } \\
\text { melhoria contínua, } \\
\text { superar } \\
\text { continuamente a } \\
\text { expectativa do cliente }\end{array}$ \\
\hline Back office & $\begin{array}{l}\text { Resume a operação } \\
\text { de suporte para } \\
\text { verificação e } \\
\text { processamento do } \\
\text { serviço }\end{array}$ & $\begin{array}{l}\text { Ainda é uma } \\
\text { atividade separada do } \\
\text { contexto que } \\
\text { contribui para a } \\
\text { realização do serviço }\end{array}$ & $\begin{array}{l}\text { Há equilíbrio e } \\
\text { integração entre } \\
\text { back office e front } \\
\text { office. Procurar } \\
\text { exceder as } \\
\text { expectativas do } \\
\text { cliente }\end{array}$ & $\begin{array}{l}\text { Atuação proativa em } \\
\text { desenvolver } \\
\text { capacidades para } \\
\text { novos serviços e } \\
\text { oportunidades }\end{array}$ \\
\hline Cliente & $\begin{array}{l}\text { Satisfação a um } \\
\text { custo mínimo }\end{array}$ & $\begin{array}{l}\text { Identifica diferentes } \\
\text { clientes por segmento } \\
\text { de negócio e } \\
\text { necessidades básicas } \\
\text { são atendidas }\end{array}$ & $\begin{array}{l}\text { Entende os clientes } \\
\text { de forma geral, } \\
\text { mas considera e } \\
\text { compreende as } \\
\text { especificidades }\end{array}$ & $\begin{array}{l}\text { Cliente é fonte de } \\
\text { ideias e estímulo à } \\
\text { geração de novos } \\
\text { serviços e valores }\end{array}$ \\
\hline $\begin{array}{l}\text { Introdução de } \\
\text { novas } \\
\text { tecnologias }\end{array}$ & $\begin{array}{l}\text { Utiliza tecnologia } \\
\text { somente quando } \\
\text { necessária para } \\
\text { sobrevivência }\end{array}$ & $\begin{array}{l}\text { Aplicação de } \\
\text { tecnologia quando } \\
\text { estudo de custo } \\
\text { justifica }\end{array}$ & $\begin{array}{l}\text { Busca por novas } \\
\text { tecnologias para } \\
\text { melhorar os } \\
\text { serviços existentes }\end{array}$ & $\begin{array}{l}\text { Tecnologia é usada } \\
\text { para gerar vantagens } \\
\text { em relação a } \\
\text { competidores } \\
\text { (pioneirismo) }\end{array}$ \\
\hline $\begin{array}{l}\text { Força de } \\
\text { trabalho }\end{array}$ & $\begin{array}{l}\text { Com muitas } \\
\text { restrições e foco é } \\
\text { na realização das } \\
\text { atividades }\end{array}$ & $\begin{array}{l}\text { Eficientes, } \\
\text { disciplinados com } \\
\text { base em } \\
\text { procedimentos }\end{array}$ & $\begin{array}{l}\text { Possuem } \\
\text { autonomia para } \\
\text { atuar no processo } \\
\text { visando atender } \\
\text { expectativa do } \\
\text { cliente }\end{array}$ & $\begin{array}{l}\text { Inovadores, criam } \\
\text { procedimentos } \\
\text { alinhados com novas } \\
\text { oportunidades }\end{array}$ \\
\hline $\begin{array}{l}\text { Gestão } \\
\text { (primeira } \\
\text { linha de } \\
\text { gestores) }\end{array}$ & $\begin{array}{l}\text { Controla } \\
\text { trabalhadores }\end{array}$ & Controla os processos & $\begin{array}{l}\text { Ouve clientes, } \\
\text { treina e facilita o } \\
\text { trabalho para } \\
\text { funcionários }\end{array}$ & $\begin{array}{l}\text { É sempre ouvido pela } \\
\text { alta administração e } \\
\text { considerado fonte de } \\
\text { novas ideias. Atua } \\
\text { visando melhorar as } \\
\text { capacidades das } \\
\text { pessoas }\end{array}$ \\
\hline
\end{tabular}

Fonte: Chase e Hayes, 1991 
Este modelo de ser facilmente adaptado da manufatura para operações de serviços com alguns pequenos ajustes, sendo que o principal é o fato do cliente estar no centro de todas as atividades operacionais. A Figura 3 ilustra esse processo que pode ser resumido a seguir:

a) Linha base performance: definição do sucesso do sistema operacional para aquelas coisas que são importantes para o cliente comparado suas necessidades e aquilo que é oferecido pela concorrência;

b) Definindo prioridades: realização de trade-off frente aos atributos em que o sistema operacional deve exceder expectativa do cliente, por exemplo, trade-off custo-preço, flexibilidade, qualidade e dependência;

c) Estabelecendo foco: alinhamento do sistema operacional, recursos e facilidades com as prioridades estabelecidas;

d) Alcançando coerência: reforço mutuo de todos os elementos do sistema operacional assegurando que tudo contribua com os objetivos da organização;

e) Incorporando Aprendizagem: coleta e disseminação de ideias obtidas através da análise da operação;

Figura 3. Paradigma da Estratégia de Manufatura aplicado em Serviços

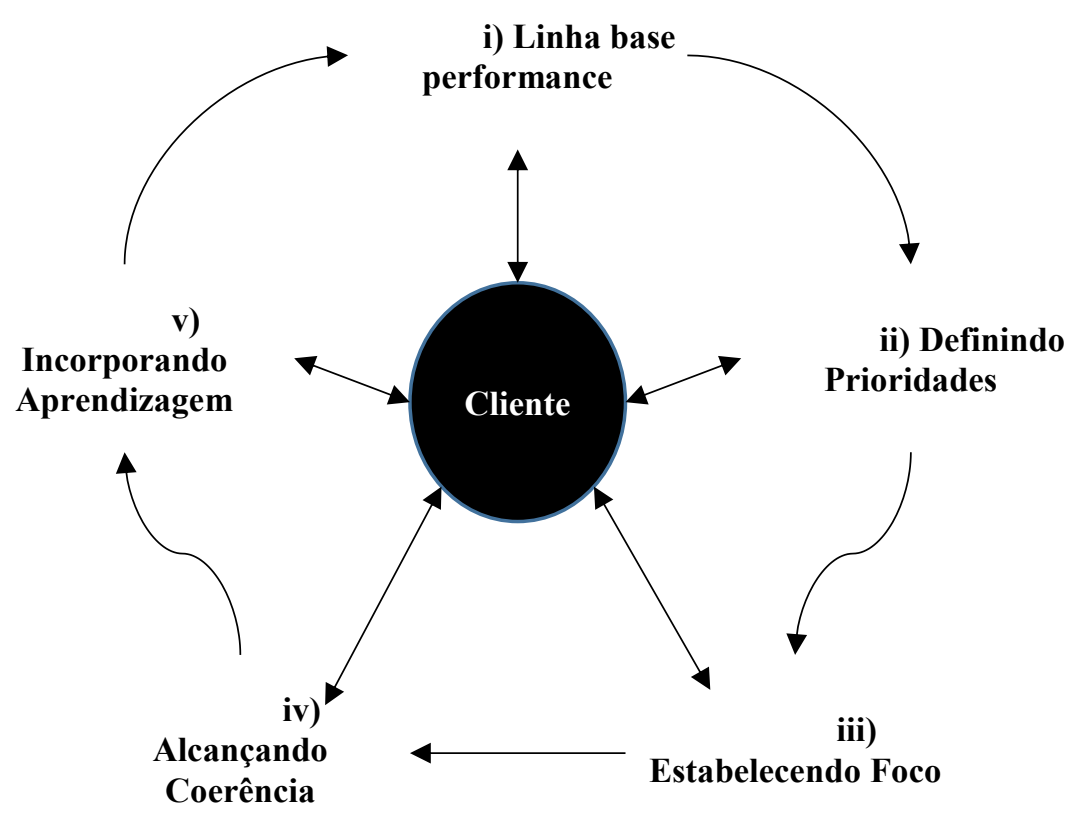

Fonte: Chase e Hayes, 1991

Segundo Chase e Hayes (1991), diferente da manufatura que possui suas operações comprimida num plano de fundo, o setor de serviços desafia seus executivos a utilizar de forma 
mais efetiva sua posição central na operação. Para isto são sugeridas três categorias de mudanças:

a) De sistema fechado para sistema aberto: Do ponto de vista de troca de informação quanto maior a ligação entre consumidor e produtor, mais fácil é de entender e responder as necessidades do cliente;

b) De foco em procedimento para foco no cliente: Foco em buscar formas de simplificar o atendimento do cliente simplificando e eliminando tarefas que não gera valor ao cliente;

c) De ilhas de atividades para empresa totalmente integrada: Papel e responsabilidade clara entre relacionamento interno "cliente-fornecedor" com reconhecimento claro no sistema de medição e recompensa da empresa;

\subsection{RELACIONANDO MODELO 4-ESTÁGIO DE COMPETITIVIDADE EM OPERAÇÕES DE SERVIÇOS E MODELO DE MATURIDADE EM MELHORIA CONTÍNUA}

A Figura 4 ilustra o modelo teórico utilizado neste estudo que foi elaborado no contexto da pesquisa teórica realizada. Este modelo compreende nas principais variáveis encontradas no modelo de 4-estágios da competividade de operações de serviços (CHASE; HAYES, 1991) e nas variáveis encontradas no modelo de maturidade de melhoria contínua (BESSANT; CAFFYN; GALLAGHER, 2001; ANAND et al, 2009). Este modelo teórico irá orientar a pesquisa de campo pelo método de estudo de caso que tem como objetivo de confirmar os principais comportamentos, ou seja, elementos que caracterizam o estágio de maturidade em diferentes níveis deste modelo.

O modelo teórico deve ser compreendido de cima para baixo. Primeiramente, existe os estágios de evolução da competitividade de operações de serviços (disponibilidade de serviço, profissionalização, diferencial competitivo alcançado e entrega de serviço com classe mundial). Conforme apresentado, as empresas tendem a se posicionar em algum desses estágios de competividade. Os estágios de competividade são influenciados por diferentes capacidades organizacionais. Estas capacidades são ilustradas no centro do modelo teórico da figura 4 conectando os "os 4 estágios de competividades" com "modelo de maturidade de melhoria contínua". Esta conexão é feita através: a) qualidade, b) back office, c) cliente, d) novas tecnologias, e) pessoas e f) gestão, como sugerido por Chase e Hayes (1991). 
Figura 4. Ilustração Modelo Teórico

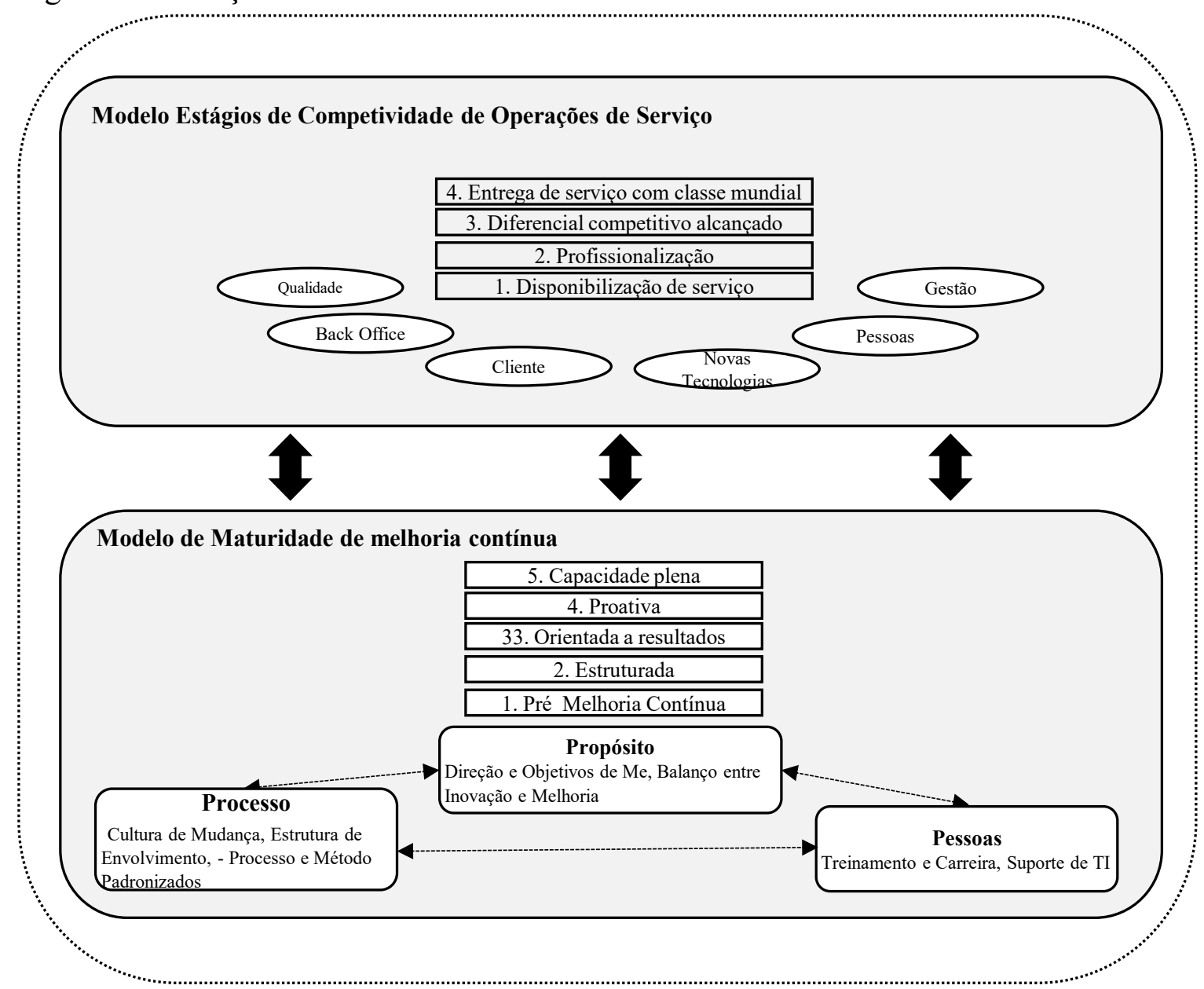

Fonte: Autor com base em Chase e Hayes (1991); Andand et al (2009); Bessant, Caffyn e Gallagher (2001)

Por outro lado, a maturidade de melhoria contínua compreende cinco diferentes níveis (pré melhoria contínua, melhoria contínua estruturada, melhoria contínua orientada, melhoria contínua proativa e capacidade plena de melhoria contínua). As empresas que possuem prática de melhoria contínua podem se posicionar em algum destes níveis de maturidade. A Figura 4 também ilustra as diferentes capacidades que podem contribuir para os diferentes estágios de maturidade. Estas capacidades estão ilustradas na base do modelo teórico interconectadas entre si: a) propósito, b) processo e c) pessoas, como sugerido por Anand et al (2009).

A Figura 5 resume os principais constructos que devem suportar a avaliação do comportamento das empresas que atuam em diferentes estágios de competitividade e diferentes níveis e maturidade de melhoria contínua. 
Figura 5 - Modelo Teórico - Constructos

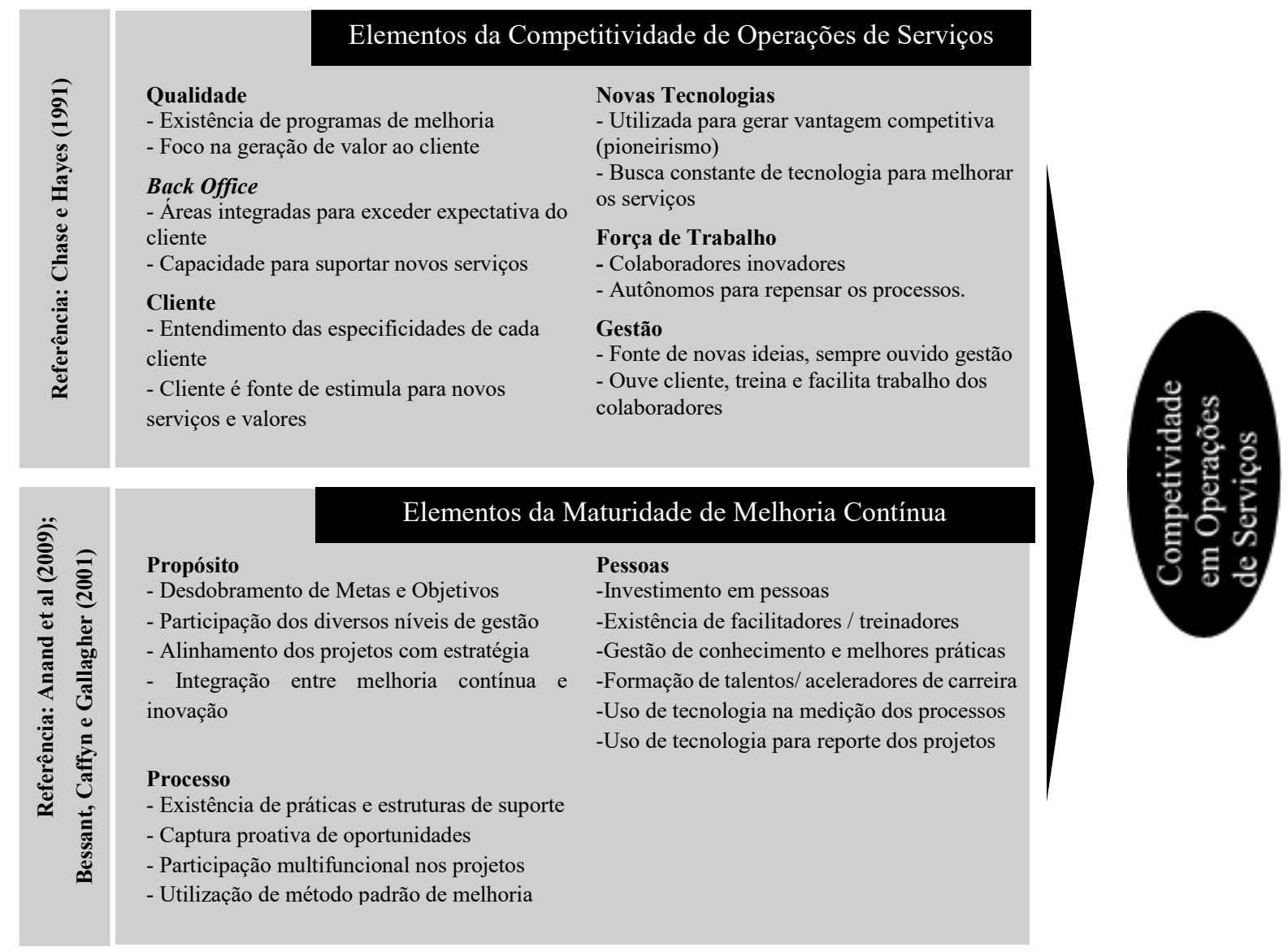

Fonte: Autor com base em Chase e Hayes (1991); Andand et al (2009); Bessant, Caffyn e Gallagher (2001)

Assim com base nesse constructo teórico, pode-se buscar elementos do campo para verificar as relações entre estágios e dimensões da competitividade de operações de serviços e os níveis de maturidade da melhoria contínua. A utilização dos constructos tanto no que diz respeito ao modelo teórico de competitividade em operações de serviços (Chase e Hayes, 1991) quanto o modelo de maturidade em melhoria continua (Anand et al, 2009; Bessant, Caffyn e Gallagher, 2001) serviu como base e fundamentação teórica para definição dos elementos de práticas a serem observados nas empresas consideradas na pesquisa de campo. 


\section{PESQUISA DE CAMPO}

Nesta sessão é apresentado a justificativa da metodologia de pesquisa considerada neste trabalho (estudo de caso múltiplo), descrição do instrumento de pesquisa utilizado e o objeto de estudo considerado. Sobre o objeto de estudo, operações hospitalares é apresentando o universo de hospitais existentes que atendem os critérios deste trabalho e, por fim, as características das empresas que aceitaram participar deste estudo de caso.

\subsection{METODOLOGIA DE PESQUISA}

Para realizar esse estudo, estabeleceu-se uma estratégia de pesquisa em três fases. Primeiramente, foi realizada uma pesquisa teórica através de uma revisão de literaturas com foco nos seguintes aspectos: (i) modelo referencial dos quatro estágios evolutivos das operações de serviço proposto por Chase e Hayes (1991), buscando as bases que sustentaram sua construção, bem como os desdobramentos de seu uso em trabalhos após sua publicação; (ii) prática da melhoria contínua em operações de serviço; (iii) competências e níveis de maturidade da melhoria contínua, partindo-se dos trabalhos de Bessant, Caffyn e Gallagher (2001).

$\mathrm{Na}$ segunda fase, com base nos resultados da revisão sistemática da primeira fase, concebeu-se um modelo para orientar uma pesquisa de campo pelo método de estudo de caso com o objetivo de identificar a relação entre níveis de maturidade de melhoria contínua e o estágio de competitividade de operações de serviços. Essa pesquisa foi realizada em empresas com foco em atendimento médico-hospitalar que possuem práticas de melhoria contínua estruturada tanto por meio de abordagens ou programas específicos como por meio de sistemas da qualidade. Também, optou-se pela seleção das empresas as seguintes características: ser finalista do prêmio nacional da qualidade ou possuir certificação por meio de referências de sistemas da qualidade ou algum critério que garanta a prática estruturada da melhoria contínua da qualidade. Para isso, foi utilizado o recurso de entrevistas e a escolha dos entrevistados levou em consideração a capacidade de responder questões tanto sobre a prática de melhoria contínua e sobre as dimensões da competitividade do modelo.

Com relação a metodologia de pesquisa, este estudo tem características de pesquisa teórica e de pesquisa de campo. A pesquisa de campo tem natureza exploratória e utiliza metodologia qualitativa do tipo estudo de caso múltiplo cujo objetivo é explorar a aplicação do modelo teórico proposto em um grupo de empresas de atendimento médico-hospitalar com o 
objetivo de identificar o nível de maturidade na prática de melhoria contínua e estágio de competividade.

Como instrumento de pesquisa foi utilizado um protocolo de entrevista e levantamento de dados (APÊNDICE A) elaborado com base o resultado da revisão bibliográfica, e contém as principais variáveis para avaliar a maturidade em melhoria contínua e identificar os estágios de competitividade em operações de serviços. Uma vez elaborado este protocolo, ele foi testado e refinado através da realização de um piloto que foi aplicado a um conjunto de profissionais seniores com experiência em gestão de melhoria contínua em empresas de diversos segmentos. Este piloto permitiu confirmar que as principais variáveis consideradas no desenho do instrumento de pesquisa estavam aderentes com a expectativa de características a serem observadas para identificar o nível de maturidade em melhoria contínua e estágio de competitividade em operações de serviços em uma determinada organização.

A escolha pelo método de pesquisa estudo de caso múltiplo está baseada no fato de que o objetivo do trabalho é explorar as características de um grupo alvo de estudo, neste caso, os hospitais selecionados de forma a propiciar a oportunidade de poder se familiarizar com os principais conceitos existentes na relação entre a maturidade em melhoria contínua e estágio de competividade em operações de serviços (FREITAS, 2000 apud PINSONNEAULT; KRAEMER, 1993).

O objeto de estudo foram três hospitais brasileiros selecionados a partir dos critérios indicados a seguir. O critério de possuir certificação da qualidade pareceu ser adequado, considerando-se que a estruturação da prática de melhoria contínua é requerimento compulsório para se obter o certificado. Assim, identificou-se na base de dados de hospitais acreditados pela ONA o total de 246 hospitais acreditados entre uma das opções mostradas no quadro 5. Entre eles, optou-se por hospitais com acreditação (ONA) Organização Nacional de Acreditação do tipo "Acreditado com Excelência" que conta com 95 hospitais. Essa escolha é porque nesse nível de acreditação os hospitais devem demonstrar cultura organizacional de melhoria contínua (ONA, 2016). 
Quadro 5 - Objeto de Estudo - Amostra hospitais brasileiros com acreditação ONA

\begin{tabular}{|c|c|c|c|}
\hline $\begin{array}{c}\text { Tipo de } \\
\text { Acreditação }\end{array}$ & Descrição & Validade & \# Hospitais \\
\hline Acreditado & $\begin{array}{l}\text { Para instituições que atendem aos critérios de } \\
\text { segurança do paciente em todas as áreas de atividade, } \\
\text { incluindo aspectos estruturais e assistenciais. }\end{array}$ & 2 anos & 68 \\
\hline Acreditado Pleno & $\begin{array}{l}\text { Para instituições que, além de atender aos critérios de } \\
\text { segurança, apresenta gestão integrada, com processos } \\
\text { ocorrendo de maneira fluida e plena comunicação entre } \\
\text { as atividades. }\end{array}$ & 2 anos & 82 \\
\hline $\begin{array}{l}\text { Acreditado com } \\
\text { Excelência }\end{array}$ & $\begin{array}{l}\text { O princípio deste nível é a "excelência em gestão". } \\
\text { Uma Organização ou Programa da Saúde Acreditado } \\
\text { com excelência atende aos níveis } 1 \text { e } 2 \text { além dos } \\
\text { requisitos específicos de nível 3. A instituição já deve } \\
\text { demonstrar uma cultura organizacional de melhoria } \\
\text { contínua }\end{array}$ & 3 anos & 96 \\
\hline
\end{tabular}

Fonte: Autor, 2017

A Figura 6 ilustra a metodologia de pesquisa destacando a importância da revisão bibliográfica na proposição do modelo teórico que combine o modelo de 4-estágios de competividade de operações de serviços e modelo de maturidade de melhoria contínua e a importância da pesquisa de campo pelo método de estudo de caso múltiplos

Figura 6 - Visão geral da metodologia de desenvolvimento da pesquisa

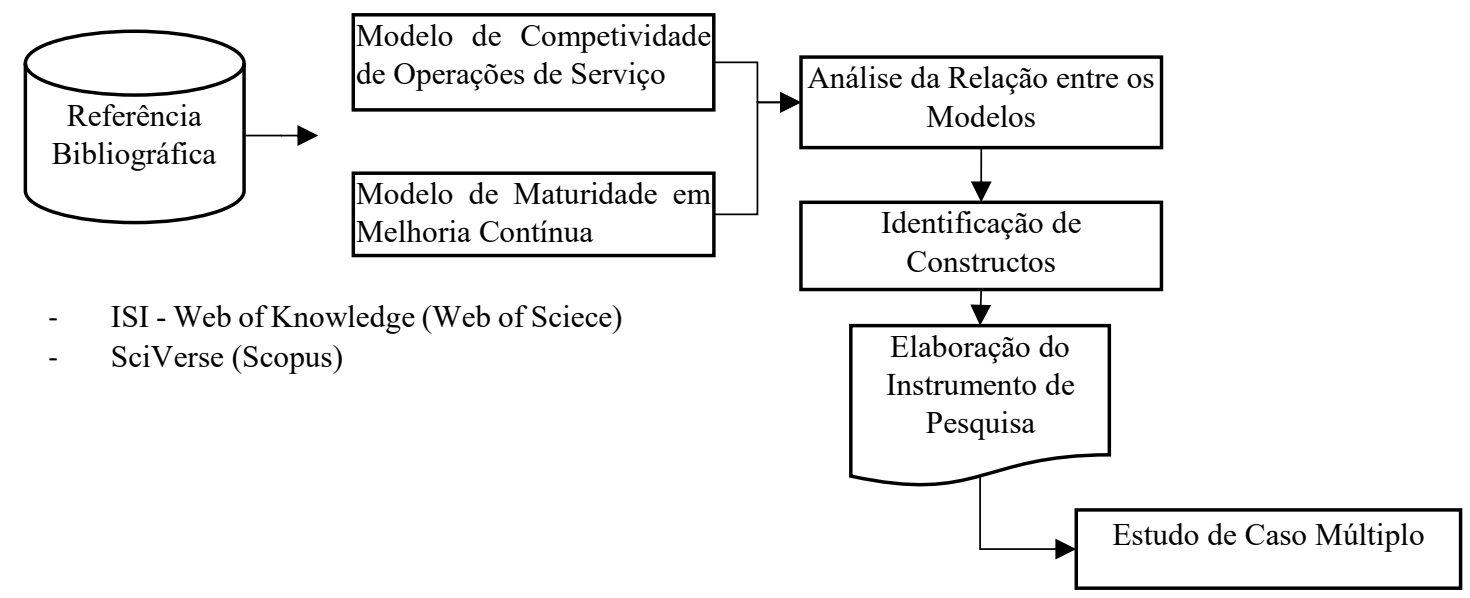

Fonte: Autor, 2017 
O quadro 6, resume as características das empresas que aceitaram participar deste estudo de caso. Depois de entrar em contato com aproximadamente 32 pessoas de cargo executivos de aproximadamente 25 hospitais, foi possível obter aceitação em participar deste estudo de pelo menos 3 empresas diferentes.

Quadro 6 - Quadro Resumo Estudo de Casos

\begin{tabular}{|c|l|l|}
\hline Caso & Características da Empresa & Fonte de Dados \\
\hline \multirow{4}{*}{ A } & - Oferece serviço médico-hospitalar & Entrevistas: \\
& - Aprox. 3 mil colaboradores & - Departamento: Melhoria Contínua de Processos \\
& - Suporte $(30 \%) /$ Atendimento $(70 \%)$ & - Cargo: Gerente Melhoria Contínua e Processos \\
& - Acreditações: Organização Nacional de & - Tempo médio empresa: 8 anos \\
& Acreditação (ONA) e Joint Commission & - Quantidade de visitas/interações realizadas: 4 \\
& International (JCI) & Fontes adicionais: Web Site da Empresa \\
\hline \multirow{3}{*}{ B } & -Oferece serviço médico-hospitalar & Entrevistas: \\
& - Aprox. 15 mil colaboradores & - Departamento: Estratégia, Processos e Projetos \\
& - Suporte (30\%)/ Atendimento (70\%) & - Cargo: Gerente Processos \\
& -Acreditações: Joint Commission International & - Tempo médio empresa: 10 anos \\
& (JCI) & - Quantidade de visitas/interações realizadas: 3 \\
\hline C & -Oferece serviço médico-hospitalar & Fontes adicionais: Web Site da Empresa \\
\hline & - Aprox. 10 mil colaboradores & Entrevistas: \\
& - Suporte (30\%)/ Atendimento (70\%) & - Departamento: Estratégia e Projetos \\
& -Acreditações: Joint Commission International & - Cargo: Gerente Processos \\
& (JCI) & - Quantidade de visitas realizas: 2 \\
& & Fontes adicionais: Web Site da Empresa \\
\hline
\end{tabular}

Fonte: Autor, 2017

\subsection{DESCRIÇÃO DAS OBSERVAÇÕES E RESULTADOS}

Esta seção foi desenvolvida com base nas observações feitas na investigação realizada nos três hospitais estudados. A descrição das observações e resultados encontrados estão divididos em duas partes: sobre a maturidade da melhoria contínua nos casos analisados (seção 3.2.1), e sobre estagio de competitividade em operações de serviços nos casos estudados (seção 3.2.2). Assim, buscou-se caracterizar os principais aspectos da gestão de melhoria contínua e suas operações de serviços nas empresas pesquisadas, com objetivo de poder classificá-las em termos de seu estágio de maturidade e competividade, bem como identificar ações que são realizadas com intuito de sinalizar melhores práticas adotadas nestas empresas.

Em relação as empresas que participaram deste estudo de caso, a empresa A é um hospital de médio porte por com aproximadamente 3 mil colaboradores possuindo acreditação nacional ONA e acreditações internacionais (JCI) Joint Commission e (AC) Accreditation Canada). A empresa B é um hospital de grande porte com aproximadamente 15 mil 
colaboradores e com acreditação internacional JCI. Por fim empresa C é um hospital de grande porte com aproximadamente 10 mil colaboradores possuindo acreditação internacional JCI.

\subsubsection{Maturidade da Melhoria Contínua nos casos analisados}

O quadro 7 apresenta um resumo das principais informações obtidas através das entrevistas e coleta de dados realizadas que permitiram compreender e classificar o nível de maturidade da melhoria continua em que se encontra cada empresa considerada neste estudo de casos. Este quadro está organizado da seguinte forma:

a) Caso: Empresa considerada no estudo de caso;

b) Missão da Empresa: descrição da principal missão e objetivo do programa de melhoria contínua na empresa;

c) Estrutura Organizacional: descrição das principais infraestruturas existentes;

d) Principais características: resumo das principais características observadas em cada empresa tendo como referência o modelo teórico - constructos (Figura 5).

Quadro 7- Classificação dos estudos de casos nos estágios de maturidade de melhoria contínua

\begin{tabular}{|c|c|c|c|}
\hline Caso & $\begin{array}{l}\text { Missão } \\
\text { Empresa }\end{array}$ & Estrutura Organizacional & Principais Características \\
\hline $\mathrm{A}$ & $\begin{array}{l}\text { - Eficácia no } \\
\text { atendimento }\end{array}$ & $\begin{array}{l}\text { - Existência de uma área } \\
\text { para gestão da processos e } \\
\text { projetos } \\
\text { - Utilização de metodologia } \\
\text { PDCA(Plan-Do-Check- } \\
\text { Analyze) e BPM (Business } \\
\text { Process Management) }\end{array}$ & $\begin{array}{l}\text { - Realização dos projetos de melhoria contínua para } \\
\text { atingimento de metas } \\
\text { - Utilização de projetos de transformação/ gestão de } \\
\text { mudança } \\
\text { - Utilização de agentes de melhoria contínua nas } \\
\text { unidades hospitalares } \\
\text { - Formalização e documentação dos processos de } \\
\text { negócio }\end{array}$ \\
\hline B & $\begin{array}{l}\text { - Excelência } \\
\text { em Qualidade }\end{array}$ & $\begin{array}{l}\text { - Existência de uma área } \\
\text { para gestão de melhoria } \\
\text { contínua e processos } \\
\text { - Utilização de metodologias } \\
\text { Lean Seis Sigma, PDCA, } \\
\text { BPM e Lean Thinking } \\
\text { - Capacidade de realização } \\
\text { de consultoria externa em } \\
\text { melhoria contínua e } \\
\text { educação para outros } \\
\text { hospitais }\end{array}$ & $\begin{array}{l}\text { - Realização dos projetos de melhoria contínua para } \\
\text { atingimento de metas e planejamento estratégico } \\
\text { - Utilização de times multidisciplinares para } \\
\text { execução dos projetos } \\
\text { - Formalização e documentação dos processos de } \\
\text { negócio } \\
\text { - Existência de governança para monitoramento de } \\
\text { performance dos processos de atingimento das } \\
\text { metas }\end{array}$ \\
\hline $\mathrm{C}$ & $\begin{array}{l}\text { - Resolução de } \\
\text { problemas } \\
\text { - Qualidade } \\
\text { técnica/acredit } \\
\text { ação }\end{array}$ & $\begin{array}{l}\text { - Estrutura de melhoria } \\
\text { contínua em fase de criação } \\
\text { - Nenhuma existência de } \\
\text { metodologia formal de } \\
\text { melhoria contínua }\end{array}$ & $\begin{array}{l}\text { - Programa de sugestões de ideias para melhoria } \\
\text { contínua }\end{array}$ \\
\hline
\end{tabular}

Fonte: Autor, 2017

Legenda: Dados obtidos através da realização de entrevista e coleta de dados nas empresas A,B e C. 
Empresa B é a que se encontra em nível mais avançado de maturidade de melhoria continua (nível 5 - capacidade plena) tendo em vista que a excelência operacional é parte de sua estratégia. Empresa B busca ser líder e inovadora na prestação de serviço médico-hospitalar e referência em gestão de conhecimento. Para atingir este objetivo a empresa possui um programa de excelência operacional consolidado e com área de gestão dedicada à melhoria contínua e processos, demonstrando domínio nas mais diversas metodologias como por exemplo, Lean, Seis Sigma, PDCA, Lean Thinking. Um dos grandes desafios que empresa B apresenta diz respeito a oferta de serviços de consultoria e capacitação em melhoria contínua a demais hospitais como parte de sua estratégia ser referência em gestão do conhecimento.

Empresa A está em nível intermediário de maturidade em melhoria contínua (nível 4 melhoria contínua proativa) com tendência de atingir no médio prazo nível 4 - pró ativo como parte de sua estratégia de ter eficácia no atendimento médico-hospitalar. O principal foco de seu programa de melhoria contínua é i) realização de projetos para atingimento das metas de negócios e ii) a governança de projetos de transformação como parte de sua estratégia de expansão e consolidação no segmento de atendimento médico-hospitalar. Para isto a empresa conta com uma área dedicada na gestão de processos e projetos com domínio em metodologias como PDCA e BPM. Um dos desafios da empresa A passa pelo desenvolvimento e consolidação da prática de melhoria contínua em suas diversas unidades médico-hospitalar tendo em vista que suas unidades apresentam diferente níveis de maturidade.

Empresa $\mathrm{C}$ é a que se encontra em menor nível de maturidade de melhoria contínua (nível 1 - Pré-Melhoria Contínua) apresentando algumas ações isoladas de melhoria contínua como por exemplo programa de sugestão e ideias de melhoria e documentação e gestão de alguns processos de negócio. No curto-médio prazo a empresa busca atingir nível 2 estruturado, tendo em vista que o principal desafio desta empresa no momento passa pela criação de uma área dedicada a gestão de processos e melhoria contínua e desenvolvimento de algumas metodologias em suas unidades como por exemplo Lean e Seis Sigma.

Com relação às práticas que contribuem para o nível de maturidade de melhoria contínua em que se encontram cada uma das empresas analisadas, a Quadro 8 sistematiza o nível de adoção de algumas práticas nestas empresas. Empresa B (classificada no nível 5 - capacidade plena de melhoria contínua) demonstra aplicação de todas as práticas que contribuem para a maturidade de melhoria contínua e foi única empresa a demonstrar alguns elementos característicos de empresas que de fato encontram-se no maior nível de maturidade de melhoria contínua, como por exemplo, a integração entre melhoria contínua e inovação (A3) e o uso dos projetos de melhoria contínua como formador de talentos e acelerador de carreira (C4). Empresa 
A (classificada no nível 4 - melhoria contínua orientada para atingimento de metas) adota as principais práticas que contribuem para existência e consolidação do programa de melhoria contínua enquanto a empresa $\mathrm{C}$ demonstra existência de apenas algumas práticas iniciais como elementos básicos típicos de empresa em que se encontra na fase pré-melhoria contínua.

As práticas comuns encontradas em todas a empresas analisadas foram:

a) alinhamento dos projetos de melhoria contínua com a estratégia da empresa (A3);

b) existência de prática e estrutura de suporte ao programa de melhoria contínua (B1);

c) formalização e padronização de processos (B5); e,

d) uso de ferramenta de medição e monitoramento dos processos (C5) evidenciando os mesmos como elementos básicos na criação um programa de melhoria contínua independente do seu nível de maturidade.

Tanto em relação ao elemento de prática $\mathrm{A} 3$-alinhamento dos projetos de melhoria contínua com estratégia da empresa quanto ao elemento de prática B2-existência de prática e estrutura de gestão do programa de melhoria contínua é tido como prática comum respectivamente (i) grande parte os projetos de melhoria contínua nascem da necessidade de atingir uma meta do negócio ou como parte de uma iniciativa estratégia da empresa, sendo sempre acompanhado da apreciação e aprovação deste projeto junto a um comitê executivo, e ii) existência de uma estrutura organizacional mínima para suporte e gestão do programa de melhoria contínua incluindo em todos os casos analisados o uso eventual quando não continuo de consultorias especializadas em treinamento e formação de facilitadores. Sobre o elemento de prática B5-formalização e padronização de processos de uma forma geral todas as empresas analisadas possuem algum nível de formalização e existência de um repositório de processos grande parte em função da necessidade de acreditação e certificação. A empresa B em particular faz uso exaustivo da criação e implementação de procedimento operacional padrão $(P O P S)$ e gestão à vista acompanhado de intenso treinamento dos colaboradores quanto a prática de gestão da rotina em todo os níveis da organização. Por fim, a prática C5-sistema de medição e monitoramento dos resultados encontramos como prática comum existência de fórum mensal onde as principais metas são monitoradas e seus resultados discutidos sempre com a presença de uma vice-presidência ou diretor executivo da unidade, sendo que algumas como como empresa A e B fazem uso de algum tipo de ferramenta para monitoramento e acompanhamento dos resultados além de utilizar fóruns mensais ou trimestrais para divulgação dos resultados e alinhamento de estratégia. 
O quadro 8 apresenta uma sistematização dessas observações, através da qual é possível classificar as empresas analisadas de acordo com seu nível de maturidade em melhoria contínua, segundo Bessant, Caffyn e Gallagher (2001). Se considerar-se as três empresas analisadas neste estudo de caso, cada empresa encontra-se em diferente nível de maturidade, empresa (A) encontra-se no Nível 4 - melhoria contínua proativa, empresa (B) encontra-se no Nível 5Capacidade Plena em melhoria contínua enquanto empresa (C) encontra-se no Nível 1- Pré Melhoria Continua.

Quadro 8 - Sistematização aspectos gerais da melhoria contínua nas empresas estudas

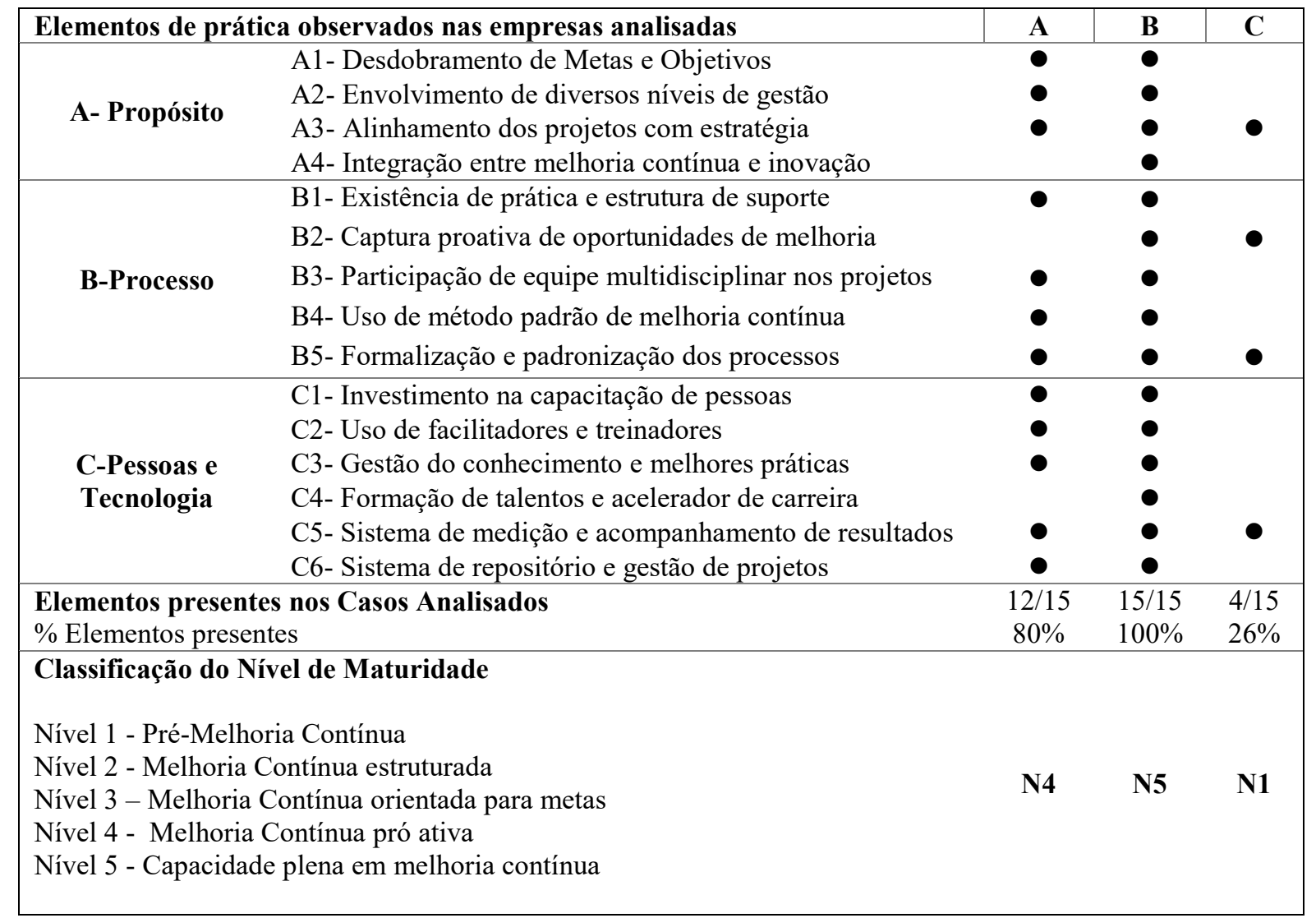

Fonte: Autor, 2017

Legenda: Dados obtidos através da realização de entrevista e coleta de dados nas empresas A,B e C.

Sobre direção e objetivo da melhoria contínua, embora todas as empresas analisadas tenham demonstrado que seus projetos de melhoria contínua devem estar alinhados com a estratégia do seu negócio e que como parte desta governança os projetos ao iniciar devem ser aprovados e posteriormente acompanhados por um comitê executivo, apenas empresa A e B demonstram possuir um processo estruturado de definição e desdobramento de metas, por exemplo enquanto na empresa B os objetivos são definidos em torno de 3 principais indicadores (Econômico-Financeiro, Qualidade Técnica e Qualidade Percebida) junto a alta administração 
para posteriormente ocorrer o desdobramento junto aos demais níveis de gestão, na empresa A suas metas também são definidas junto a alta administração sendo que como ferramenta de apoio e gestão esta faz uso de Balance Score Card que auxilia também na comunicação junto aos demais níveis da empresa.

Em relação ao balanço entre prática de melhoria contínua com inovação, demonstrando a capacidade da empresa de incorporar estabilidade e objetivos de mudança com melhoria de processos e projetos de desenho de novos processos, apenas a empresa B (nível 5 - capacidade plena de melhoria contínua) foi a única a demonstrar elementos de integração entre melhoria contínua e inovação como por exemplo uso de metodologia como Design Lean Thinking em projetos que buscam repensar seus processos de negócio como parte da estratégia da empresa de ser líder e inovadora na prestação de serviço médico-hospitalar. Esta característica observada reforça a importância da consolidação das práticas de melhoria contínua como base precursora da prática de inovação, tendo em vista que a sucessão de melhorias incrementais possibilita a geração de melhorias radicais além do que a cultura fortemente voltada para excelência operacional ou melhoria contínua, como observada no caso da empresa $\mathrm{B}$, auxilia na cultura de mudança, gerando um ambiente propício para inovação.

Em relação à cultura de mudança, enquanto empresa $\mathrm{C}$ demonstra como boa prática a utilização de processo para captura de ideias ou sugestões de melhorias através de sua intranet além dos diferentes eventos com executivos para comunicação da estratégia e desafios, empresa A reconhece que uma prática comum no seu negócio para promover maior envolvimento das pessoas junto as iniciativas de melhoria contínua é o processo de acreditação pois este mobiliza diferentes áreas e responsabilidades em torno de um objetivo comum, a empresa B demonstra possuir uma cultura de mudança mais madura, seja influenciada pela longevidade do seu programa de melhoria contínua, seja através do treinamento e formação de diversos multiplicadores ao longo dos anos ou pelo reconhecimento que o envolvimento dos colaboradores na agenda de melhoria contínua é diária, pois estes são incentivados, motivados e desafiados diariamente na busca por resultados de forma que a cultura de mudança está no DNA na empresa.

Empresas que apresentam maior níveis de maturidade, como as empresas A e B, demonstram como prática comum durante a realização de alguma iniciativa de melhoria contínua o envolvimento de equipe multidisciplinar, enquanto empresa B reconhece como boa prática a definição e envolvimento de equipes multidisciplinares logo no início do projeto como forma de garantir a representatividade de todas as áreas responsáveis pelos processos em escopo, Também, a empresa A estabelece como prática comum a definição de um plano de 
gestão de mudança junto ao diretor responsável pela área impactada pelo projeto como forma de garantir a participação das pessoas chaves nesses processos.

Com relação a uso de processo padronizado de melhoria contínua, embora as empresas A e B demonstrarem a utilização de metodologias adequadas, apenas a empresa B faz uso da metodologia Lean Six Sigma e Design Lean Thinking como já observado anteriormente, além desta também utilizar demais metodologias para gestão da rotina e gestão de processo, como por exemplo PDCA e BPMN e metodologias e ferramentas do Lean, como, por exemplo, Value Sream Map e Kaizen. O domínio e utilização de mais de uma metodologia está associado com seu nível de maturidade tendo em vista que na medida em que os esforços necessários para o atingimento dos benefícios se faz cada vez maiores em empresas com maior nível de maturidade, fazendo-se, portanto, necessário o uso de metodologia e ferramentas mais robustas.

Com exceção da empresa $C$, que se encontra no nível 1(pré-melhoria contínua) e reconhece estar em processo de estruturação do programa, as empresas A e B possuem como prática comum o investimento em treinamento de seus multiplicadores, como por exemplo formação de treinadores ou facilitadores, incluindo a utilização de parceiros na capacitação interna e externa sendo que alguns de seus multiplicadores inclusive possuem certificações internacionais em gestão de processo de negócio. No caso da empresa $\mathrm{B}$, esta foi a única demonstrar que seu programa de melhoria contínua está relacionado com o plano carreira de seus colaboradores, onde a participação em projetos de melhoria contínua é um diferencial importante para posições de liderança global, além de considerar a participação e liderança em projetos de melhoria como um fator determinante para avaliação de resultados.

Quanto ao suporte de tecnologia nas iniciativas de melhoria contínua, empresas A e B reconhecem a parceria com a área de TI como uma boa prática na medida em que oportunidades de simplificação e automação de processos são realizadas como parte das iniciativas de revisão e melhoria de processos, além do que, ambas as empresas utilizam de alguma forma ferramentas e sistemas para gestão do repositório de projetos e compartilhamento de melhores práticas entre as diversas áreas. Ainda com relação ao uso de tecnologia, uma característica comum de empresas do setor de serviço médico-hospitalar é que estas estão sujeitas ao processo de acreditação e certificação por organismos locais e internacionais, fato este que, de alguma forma requer que as empresas tenham um mínimo de formalização e organização de seus processos de negócio sustentado por sistemas de informação. Neste contexto, a empresa $\mathrm{C}$ acaba utilizando alguma ferramenta para documentação dos processos embora estes estejam limitados aos processos alvo da acreditação, ao passo que empresas em maiores níveis de maturidade, 
como, por exemplo, empresas A e B possuem esta prática de documentação dos processos e governança na manutenção dos mesmos como prática generalizada na organização.

\subsubsection{Estágio de competitividade em operações de serviços nos casos analisados}

O quadro 9 apresenta um resumo das principais informações obtidas através das entrevistas e coleta de dados realizadas que permitiram compreender e classificar o estágio de competividade de operações de serviços em que se encontra cada empresa considerada neste estudo de caso. Este quadro está organizado da seguinte forma:

a) Caso: Empresa considerada no estudo de caso;

b) Visão da Empresa: descrição da visão da empresa;

c) Estrutura organizacional: principal infraestrutura existente na empresa para apoiar sua competitividade operacional de serviços;

d) Principais características: resumo das principais características observadas em cada empresa tendo como referência o modelo teórico - constructos (Figura 5)

Empresa B é a que se encontra em estágio mais avançado de competitividade de operações de serviços (estágio 4 - entrega de serviço de classe mundial) tendo em vista que sua visão de ser líder e inovadora na assistência médico-hospitalar e referência na gestão do conhecimento no setor. Para alcançar esta visão, a empresa B coloca como principal desafio encantar o cliente através de um atendimento inovador e de excelência, para isto ela conta com segmentação por unidade de negócio como forma de tratar diferente necessidades dos clientes e uma integração entre back office e front office como visão clara de exceder a satisfação do cliente. Algumas práticas que foram identificadas na empresa B, i) foco na melhoria da experiência do cliente por meio da prática de inovação, ii) utilização de indicadores para medir de diversas formas a experiência dos clientes e em diferentes níveis da cadeia de valor, iii) uso de pesquisas direcionadas e voluntarias para captura constante da "voz do cliente", e iv) segmentação do cliente por unidade de negócio e necessidade. 
Quadro 9 - Classificação das empresas analisadas nos estágios de competitividade de Operações de Serviços

\begin{tabular}{|c|c|c|c|}
\hline Caso & $\begin{array}{l}\text { Visão da } \\
\text { Empresa }\end{array}$ & Estrutura Organizacional & Principais Características \\
\hline $\mathrm{A}$ & $\begin{array}{l}\text { - Atendimento } \\
\text { de alta eficácia } \\
\text { - Respeito a } \\
\text { ética e o } \\
\text { indivíduo em } \\
\text { seu contexto } \\
\text { social. }\end{array}$ & $\begin{array}{l}\text { - Existência de Diretoria para } \\
\text { relacionamento com Médico e } \\
\text { Clientes } \\
\text { - Utilização de Centro de } \\
\text { Serviços Compartilhados para } \\
\text { padronização e integração de } \\
\text { serviços entre as unidades } \\
\text { - Existência de área de } \\
\text { Educação Continuada para } \\
\text { desenvolvimento de colabores e } \\
\text { médicos }\end{array}$ & $\begin{array}{l}\text { - Realização de benchmark entre as unidades } \\
\text { - Diferentes canais para captura da "voz do } \\
\text { cliente": pesquisa, site, telefone, etc. } \\
\text { - Utilização de indicadores de qualidade } \\
\text { técnica (assistenciais), pesquisa de satisfação } \\
\text { com médicos e pacientes } \\
\text { - Realização de auditorias internas externas } \\
\text { (acreditação) } \\
\text { - Monitoramento da qualidade percebida pelo } \\
\text { cliente }\end{array}$ \\
\hline $\mathrm{B}$ & $\begin{array}{l}\text { - Excelência de } \\
\text { qualidade no } \\
\text { atendimento da } \\
\text { saúde } \\
\text { - Geração do } \\
\text { conhecimento e } \\
\text { da } \\
\text { responsabilidade } \\
\text { social }\end{array}$ & $\begin{array}{l}\text { - Segmentação por unidade de } \\
\text { negócio para tratar diferente } \\
\text { necessidades } \\
\text { - Integração back e front office } \\
\text { com visão sistêmica em } \\
\text { encantar o cliente }\end{array}$ & $\begin{array}{l}\text { - Benchmark com outras instituições } \\
\text { referência } \\
\text { - Foco na melhoria da experiência do cliente } \\
\text { por meio de inovação } \\
\text { - Utilização de indicadores de qualidade em } \\
\text { todo os níveis da organização } \\
\text { - Pesquisas direcionadas e voluntárias para } \\
\text { captura da "voz do cliente" } \\
\text { - Segmentação do cliente por unidade de } \\
\text { negócio/ necessidades }\end{array}$ \\
\hline $\mathrm{C}$ & $\begin{array}{l}\text { - } \\
\text { Desenvolviment } \\
\text { o ações } \\
\text { integradas de } \\
\text { assistência } \\
\text { social, de saúde, } \\
\text { de ensino e de } \\
\text { pesquisa. }\end{array}$ & $\begin{array}{l}\text { - Existência de Diretoria de } \\
\text { Experiência do Paciente } \\
\text { - Baixa/Média integração de } \\
\text { operações } \\
\text { - Existência de Centro de } \\
\text { Ensino e Pesquisa }\end{array}$ & $\begin{array}{l}\text { - Benchmark/Parceiras com Hospitais } \\
\text { referências } \\
\text { - Utilização de indicadores de reclamações, } \\
\text { tempo de atendimento e experiência do } \\
\text { cliente } \\
\text { - Projetos de melhoria no fluxo e experiência } \\
\text { do paciente } \\
\text { - Segmentação do cliente por criticidade, } \\
\text { fluxo e tipo de paciente }\end{array}$ \\
\hline
\end{tabular}

Fonte: Autor, 2017

Legenda: Dados obtidos através da realização de entrevista e coleta de dados nas empresas A,B e C.

Empresa A pode ser classificada no estágio 2 - diferencial competitivo alcançado refletindo sua visão de negócio que busca prestar um atendimento de alta eficácia. Como forma de alcançar esta visão, empresa A possui um centro de serviços integrados que facilita na padronização e integração dos serviços em suas diferentes unidades, além contar com áreas de relacionamento com médicos e pacientes, além da educação continuada que suporta seus objetivos de capacitação e desenvolvimento de seus colaboradores quanto à satisfação do cliente e domínio e disciplina de execução de seus processos operacionais. Algumas práticas que foram identificadas na empresa A são i) prática de realizar benchmark entre suas unidades como forma de buscar o alto desempenho e oportunidades de padronização, ii) utilização de diferentes canais de "voz do cliente", e iii) utilização de diversos indicadores para avaliar 
satisfação do cliente como qualidade técnica do atendimento, pesquisa de satisfação dos clientes e médicos.

A empresa C, por fim, foi classificada no estágio inferior de competividade de operações de serviços (estágio 2 - profissionalização). Embora sua visão é ser reconhecida internacionalmente pela excelência, liderança e pioneirismos em assistência à saúde e na geração de conhecimento o que indica seu potencial, as evidências mostram que ela encontrase em um estágio transitório, algo reforçado pelas principais características observadas, como por exemplo, a recém criada diretoria de experiência do paciente, existência de um centro de ensino e pesquisa, e plano de aumentar integração entre suas operações que hoje são classificadas como baixa/média integração. Algumas práticas encontradas na empresa C são i) realização de benchmark e parcerias com hospitais de referência como forma de acelerar sua transformação, ii) utilização de diversos indicadores relacionando experiência do cliente com performance de seus processos, iii) projetos de melhoria no fluxo do paciente, e iv) segmentação no atendimento do cliente de acordo com sua criticidade, fluxo de atendimento e tipo de paciente.

Com relação ao nível de competividade em que se encontra cada capacidade observada pelo modelo de Chase e Hayes (1991), o quadro 10 sistematiza o nível em que se encontra cada empresa analisada. A empresa A demonstra estar consolidando-se no estágio 3 - diferencial competitivo como oportunidade de evoluir as capacidades i) cliente e ii) força de trabalho que se encontram em estágio inferior (estágio 2- profissionalização). A empresa B demonstra buscar consolidar-se no estágio 4 - entrega de serviço de classe mundial com desafios de evoluir as capacidades i) back office, ii) introdução de novas tecnologias que por sua vez encontram-se em estágio inferior as demais (estágio 3 - diferencial competitivo alcançado). Por fim, empresa C é a que apresenta maiores desafios, pois, embora encontra-se no estágio 2 - profissionalização e demonstra evolução das capacidades i) introdução de novas tecnologias e ii) gestão, a empresa $\mathrm{C}$ tem como desafio ainda evoluir a capacidade i) back office que se encontra no menor estágio de competividade (estágio 1- disponibilização de serviço). 
Quadro 10 - Comparativos entre os estágios de competividade para empresas analisadas

\begin{tabular}{|c|c|c|c|c|}
\hline $\begin{array}{l}\text { Estágios/ } \\
\text { Capacidades }\end{array}$ & $\begin{array}{l}\text { 1.Disponibilização } \\
\text { de Serviço }\end{array}$ & 2.Profissionalização & $\begin{array}{l}\text { 3.Diferencial } \\
\text { competitivo } \\
\text { alcançado }\end{array}$ & $\begin{array}{l}\text { 4.Entrega de serviço } \\
\text { com classe mundial }\end{array}$ \\
\hline $\begin{array}{c}\text { Qualidade de } \\
\text { Serviço } \\
\text { Back Office }\end{array}$ & & & &
\end{tabular}

Fonte: Autor, 2017

Legenda: Dados obtidos através da realização de entrevista e coleta de dados nas empresas A,B e C.

Por fim, o quadro 11 sistematiza o nível de adoção de algumas práticas entre as empresas analisadas o que que contribui para entender as principais práticas comum e as principais variações que explicam as diferenças entre o nível de competividade de operações de serviços nas empresas analisadas. Com base nesta sistematização é possível classificar as empresas analisadas de acordo com seu estágio de competitividades em operações de serviços, segundo Chase e Hayes (1991).

A empresa B (classificada no estágio 4 - entrega de serviço de classe mundial) demonstra aplicação de todas as práticas que contribuem para estar no estágio mais avançado de competividade e também é a única empresa a demonstrar alguns elementos característicos de empresas que se encontram neste estágio, como por exemplo, fazer uso da melhoria contínua como forma de exceder a expectativa de seu cliente (A2), utilizar a "voz do cliente" para criação de novos serviços (B2) e colaborar possuir autonomia para inovar (E2). A Empresa A. classificada no estágio 3 - diferencial competitivo alcançado, demonstra as principais práticas que consolidam este estágio de competividade, assim como empresa $\mathrm{C}$ apresenta algumas práticas que reforçam sua posição no estágio 2 - profissionalização. 
Quadro 11 - Sistematização aspectos gerais da competitividade em operações de serviços

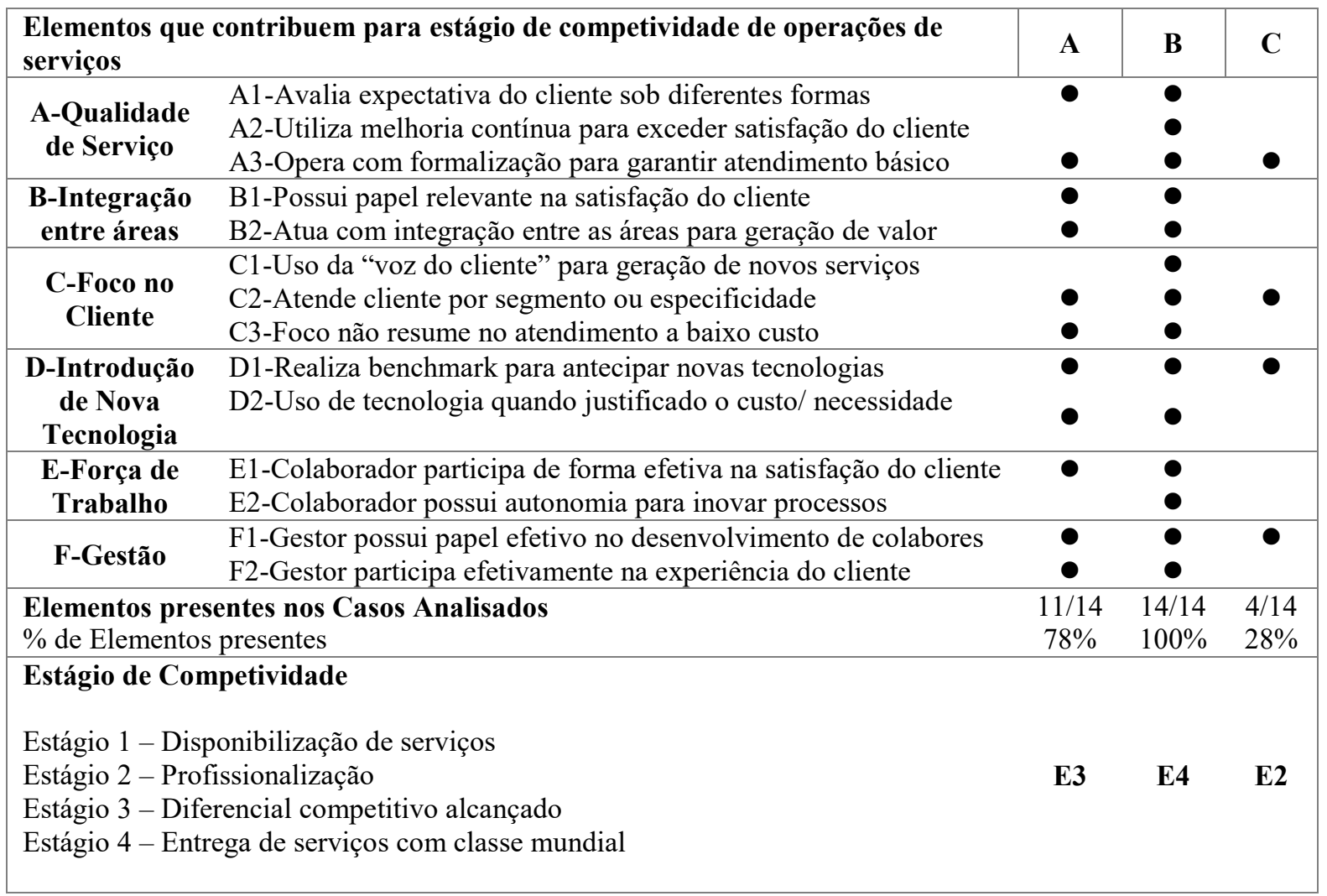

Fonte: Autor, 2017

Legenda: Dados obtidos através da realização de entrevista e coleta de dados nas empresas A,B e C.

As práticas comuns encontradas entre as empresas analisadas foram:

a) operar com maior formalização de forma garantir o atendimento básico (A3);

b) atender cliente por seguimento ou necessidade (E2);

c) realização de benchmark para antecipar novas tecnologias (D1); e,

d) gestor possuir papel ativo no desenvolvimento dos colaboradores (F1).

De uma forma geral, com relação ao item a) operar com maior formalização de forma garantir o atendimento básico (A3), foi observado que todas as empresas analisadas possuem um nível mínimo de formalização e controle de suas operações com objetivo de garantir nível aceitável de atendimento, o que é algo exigido não apenas pela natureza da operação, mas também pelo nível de competitividade a que estão expostas através das acreditações e certificações.

Sobre o item b) atender cliente por seguimento ou necessidade (E2), foi constatado que, de uma forma geral, todas as empresas analisadas aparentam realizar seu atendimento dos seus clientes de forma segmentada, quer seja quando esta segmentação ocorre em função de uma 
prioridade ou fluxo de atendimento como observado na empresa $\mathrm{C}$ ou quando esta segmentação é definida por prática de gestão em diferentes unidades de negócio ou perfis de clientes com diferentes necessidades o que exige, portanto, diferente formas de capturar e compreender as necessidades dos clientes, como, por exemplo, onde a empresa A possui uma estrutura de vicepresidência de saúde responsável com conectar todos os processos de ouvidoria e pesquisa e satisfação do cliente com a vice-presidência de operações, ou no caso da empresa B que busca disseminar como parte de sua cultura a habilidade de qualquer colaborador deve estar atento em buscar ouvir sempre o cliente e encantá-lo com o seu atendimento.

Em relação ao item c) realização de benchmark para antecipar novas tecnologias (D1), todas as empresas demonstram como prática comum pela busca de melhoria continua e antecipação de uma vantagem competitiva, a realização de benchmark não apenas nacionalmente como internacional com hospitais de referência no que diz respeito antecipar o lançamento de uma tecnologia ou busca por uma prática inovadora de gestão, sendo que, este benchmark não se resume a hospitais de referência mas também grandes fornecedores e parceiros de tecnologia. Adicionalmente, para as empresas B e C a realização constante de benchmark é algo fortemente alinhado com sua visão de negócio que busca não apenas oferecer um serviço de atendimento médico-hospitalar de excelência, mas também o desenvolvimento e gestão de conhecimento através de suas unidades de educação, ensino e pesquisa.

Por último, sobre a prática comum d) gestor possuir papel ativo no desenvolvimento dos colaboradores (F1), as empresas analisadas, quer seja em função da natureza de seu próprio negócio que requer servir e atender seus clientes que muitas vezes se apresentam com necessidades diferentes, requerendo, portanto, diferentes níveis de atenção e atendimento, ou quer seja em função de sua estratégia em prover um serviço de qualidade e excelência como forma de se diferenciar entre demais concorrentes, faz com que o gestor tenha um papel fundamental no desenvolvimento de seus colaboradores. Nas empresas analisadas, embora o gestor não tenha em muitos dos casos um papel e contato de atendimento direto ao cliente, ele é responsável por assegurar que seus colaboradores tenham claro a estratégia e missão da empresa e como isto deve refletir na forma como cada colaborar executa seu processo e se relaciona com seus clientes nos diferentes níveis de interação. A expectativa sobre a importância do papel de gestor no desenvolvimento dos colaboradores pode variar de acordo com as empresas analisadas, onde, por exemplo, na empresa B define-se que cada gestor deve liderar pelo exemplo seus colaboradores independentemente do nível que este gestor se encontra na organização, ou, como no caso da empresa A que tem como expectativa que o gestor atue efetivamente junto aos seus colaboradores com objetivo de identificar necessidades 
de desenvolvimento e propor junto com a área de recursos humanos soluções para estas necessidades. Por fim, como no caso da empresa C, que embora seu modelo de desenvolvimento organizacional esteja em fase de desenvolvimento, reforça que seus gestores têm total liberdade para buscar sempre o desenvolvimento de seus colaboradores sem necessariamente depender de uma interferência da área de recursos humanos.

Sobre a capacidade de qualidade de serviço, embora todas as empresas analisadas terem apresentado de alguma forma práticas tanto de formalização e padronização de seus processos como práticas de controle e monitoramento de seus processos, a maturidade dessas práticas variam de empresa para empresa o que por sua vez reflete na capacidade de cada empresa conectar a expectativa e necessidades do cliente com ações e iniciativas de melhoria continua, capacidade esta que fica evidente quando observado a empresa B (ver quadro 8) como a única empresa que demonstra capacidade de utilizar sua capacidade de melhoria continua como forma de buscar exceder as necessidades de seus clientes. Embora empresa A possuir processos que utilizam as informações de diferentes canais de pesquisa e captura da satisfação de seus clientes, as oportunidades e sugestões de melhorias devem passar sempre por um comitê executivo para deliberar sobre novos serviços e oportunidades, o que por sua vez pode impactar no tempo de resposta entre a captura de uma necessidade do cliente e sua implementação quando ocorre de fato um impacto efetivo na percepção do cliente. Diferente da empresa A, a empresa B que também possui fóruns de governanças para tomada de decisão sobre criação de novos serviços ou grandes mudanças em seus processos, busca através de seu programa de excelência operacional oferecer ao cliente um atendimento de excelência e inovador, exigindo, portanto, através de suas diversas iniciativas de melhoria continua um tempo de resposta curto entre a captura das necessidades de seus clientes e a conversão destas pequenas e rápidas ações de melhoria que gera uma percepção positiva no cliente.

Em relação a capacidade integração de back office e front office, apenas a empresa A possui seu back office estruturado na forma de um centro de serviço compartilhado para atender diferentes unidades do grupo e assim assegurar máximo de padronização das operações de suporte e liberação de recursos para processos e operações de maior valor ao cliente. A empresa $\mathrm{B}$, diferente da empresa $\mathrm{A}$, não possui suas operações de back office estruturadas como centro de serviços compartilhados, porém assegura que toda operação de back office esteja integrada com as operações de front office através de uma visão clara e completa sobre a operação de negócio em torno do cliente, além do que todos os processos são formalizados e padronizados com o objetivo de deixar claro papéis e responsabilidades de cada um em superar expectativa do cliente, além de ser realizados treinamento on the job com os colaboradores do back office 
como forma de capacitação sobre a importância do seu papel na visão geral de atendimento e superação das necessidades do cliente.

Sobre a capacidade foco no cliente, embora as empresas A e C possuam como práticas tanto a medição e controle de seus processos como a captura da satisfação de seus clientes sob os mais diversos canais, apenas a empresa B demonstra capacidade no uso efetivo da " $v o z$ do cliente" para geração de novas oportunidades, suportada por sua visão de busca pela excelência e inovação no atendimento médico-hospitalar, visão está que é possível de ser atingida dado seu estágio de maturidade em melhoria contínua, principalmente sob sua capacidade de integrar metodologia de melhoria contínua com inovação de processos (balanço entre prática de melhoria contínua com inovação) e sob prontidão mudar seus processos (cultura de mudança) como algo que faz parte do DNA da empresa, o que fica evidente quando gestores entrevistados na empresa A afirmam que é papel de todos na organização encantar o cliente, buscando sempre superar suas expectativas.

Para a capacidade de introdução de nova tecnologia, todas as empresas analisadas, quer seja pela natureza do seu negócio de atendimento médico-hospitalar demandar alto volume de investimentos em tecnologias, ou, quer seja, em virtude de buscar antecipar uma vantagem competitiva, demonstraram de uma forma geral capacidade proativa em realizar benchmark com objetivo de identificar e antecipar novas tecnologias. Neste contexto, a empresa B analisada difere por ir um passo além, onde a busca por novas tecnologias não se resume apenas as principais atividades de uma operação hospitalar, mas também qualquer tecnologia que possa proporcionar uma melhor experiência a seus clientes seja este de sua unidade de atendimento médico-hospitalar ou de suas unidades de ensino e pesquisa.

Sobre a capacidade de força de trabalho, tanto a empresa A quanto a empresa B demonstram como prática assegurar que seus colaboradores estejam preocupados em atender as necessidades dos clientes seja estando diretamente envolvidos durante o atendimento do cliente ou indiretamente através as atividades de suporte no back office. Essa preocupação é refletida na forma como os processos são formalizados e monitorados através dos mais diversos indicadores de atendimento e satisfação do cliente, e na forma como os colaboradores são intensamente treinados. No caso da empresa B, esta capacidade vai um nível acima, tendo em vista a cultura da empresa de autonomia para seus colaboradores para buscar formas de melhor atendimento do cliente e inovar no seu atendimento com objetivo de encantar o mesmo. Sobre a empresa $\mathrm{C}$, embora ela promova o envolvimento de seus colaboradores em iniciativas de melhoria continua e também realiza diversos treinamentos como forma de capacitá-lo para atendimento do cliente, seu modelo de desenvolvimento organizacional é que deverá contribuir 
para um maior desenvolvimento e maturidade nesta capacidade, podendo ser fundamental para atingir um estágio superior.

Em relação a capacidade de gestão, todas as empresas analisadas demonstram uma capacidade onde sua linha de gestão trabalha com o objetivo de desenvolver seus colaboradores seja através da identificação de necessidades de treinamento e capacitação ou do desdobramento dos objetivos da empresa e apoiá-los no atingimento das metas. No caso das empresas A e B, existe a expectativa de que os gestores contribuam para o atingimento e superação da expectativa de seus clientes, seja através de contribuição de ideias ou participação em projetos de melhoria continua, ou, até mesmo, encorajando e apoiando suas equipes em ouvir seus clientes e contribuir com fontes de oportunidades de melhoria no atendimento. No caso particular da empresa B, esta característica do gestor, de atuar como um grande facilitador da busca pela excelência e inovação no atendimento, está relacionado também com o fato que seu programa de melhoria continua é integrado com o plano de carreira de formação de novos líderes de negócio, portanto, tanto gestor quanto o colaborador estão sempre expostos às oportunidades de aceleração de sua trajetória de carreira na medida em que conseguem encantar seus clientes.

\subsection{DISCUSSÃO DOS RESULTADOS}

A contraposição entre literatura especializada e o modelo teórico proposto, e os resultados obtidos através do estudo de caso de três empresas permite as seguintes discussões.

Primeiramente, de fato, nem todas as empresas analisadas estão no mesmo nível de maturidade de melhoria contínua, e também não se encontram no mesmo estágio de competitividade de operações de serviços. Apenas a empresa B poderia ser classificada no nível 5- capacidade plena de melhoria contínua e no estágio 4- entrega de serviço de classe mundial. A empresa A está no nível 3- melhoria contínua orientada para atingimento de metas e no estágio 3- diferencial competitivo alcançado e, por fim, empresa C está no nível 1- pré melhoria continua e estágio 2- profissionalização. Embora apenas uma empresa se encontra no nível mais alto de melhoria contínua e estágio mais avançando de competitividade de operações, todas as demais apresentam práticas em diferentes níveis de maturidade e desenvolvimento nestas duas áreas de conhecimento.

De acordo com o modelo teórico apresentado na seção 2.4, o nível de maturidade da melhoria contínua em que se encontra uma empresa pode influenciar no estágio de competitividade em que a mesma se encontra. Elementos como a direção e objetivo do 
programa de melhoria contínua, o balanço entre melhoria contínua e inovação, a cultura de mudança em uma empresa, a estrutura com que os colaboradores são envolvidos nos programas de melhoria contínua, a padronização e formalização dos processos, a utilização de um método padrão de melhoria, o suporte de tecnologia, capacitação e, por fim, a oportunidade de desenvolvimento de pessoas não apenas contribuem diretamente para o nível de maturidade de uma programa de melhoria contínua mas também influencia o nível de competividade em que sua operação de serviços pode atuar. A empresa B foi observada como a empresa que mais aderência possui tanto às práticas de melhoria contínua (100\%, de acordo com Quadro 6) e no estágio de competividade de sua operação de serviços (100\%, de acordo com Quadro 11), destacando-se como referência quanto ao propósito de seu programa de melhoria, processo de melhoria continua existente na empresa e nível de envolvimento das pessoas em torno do programa.

Com relação à empresa $\mathrm{A}$, que se apresentou como a segunda empresa que possui maior aderência em relação a prática de melhoria continua (80\%, de acordo com Quadro 6) e ao estágio de competividade de sua operação de serviços (78\%, de acordo com Quadro 11). Se observados os principais elementos que faltam para que ela tenha o maior nível de maturidade em seu programa de melhoria contínua será dado conta que são elementos que capacitam para que a mesma possa evoluir do estágio 3- diferencial competitivo alcançado para estágio 4entrega de serviço de classe mundial. Estes elementos são: integração entre melhoria contínua e inovação, captura pró ativa de oportunidades de melhoria, formação de talentos e acelerador de carreira.

Sobre a empresa C, que foi observada como a empresa que demostrou menor nível de aderência à prática de melhoria contínua (26\%, de acordo com Quadro 6) e ao estágio de competividade de sua operação de serviços (28\%, de acordo com Quadro 11). Quando observados os principais elementos de práticas existentes na empresa $\mathrm{C}$, fica evidente que a mesma se encontra no início de uma jornada de evolução de seu programa de melhoria contínua, fazendo uso de elementos básicos como gestão da rotina, formalização e padronização dos processos, medição e monitoramento das metas e indicadores, captura de ideias e sugestões de melhoria continua. Porém, ainda com uma estrutura em desenvolvimento e sem a utilização de um método padrão de melhoria, e tão pouco tendo realizado grandes esforços de desenvolvimento e capacitação de treinadores e facilitadores.

Em relação à capacidade de balancear melhoria continua e inovação e a utilização do programa de melhoria continua como formador de líderes e acelerador de carreira, além da empresa B nenhuma outra empresa apresentou essas capacidades. 
Ainda em relação a empresa $\mathrm{B}$, que se encontra no maior estágio de competitividade de operações e também possui maior nível de maturidade da melhoria contínua, e que tem como visão oferecer um serviço de excelência e ser líder em inovação, observou-se que possui maior nível de competitividade nos elementos (qualidade, cliente, força de trabalho e gestão) e também foi única, entre as empresas analisadas, a possuir como elemento de prática "balanço entre melhoria contínua e inovação" e "contribuição do programa de melhoria contínua no desenvolvimento e formação de seus líderes", o que permite reconhecer que nesta empresa em questão ter o maior nível de maturidade da melhoria contínua faz parte de sua estratégia em ter excelência no atendimento médico-hospitalar e ser líder inovadora neste segmento. Empresas como a empresa A e que têm como parte de sua visão ser líder e inovadora no seu segmento de atuação exige que sua alta liderança valorize a excelência de sua operação e cultura de mudança como facilitadores para encantar seus clientes.

Um dos resultados importantes deste estudo é poder evidenciar o relacionamento existente entre nível de maturidade da melhoria contínua e estágio de competitividade em operações de serviços. É possível dizer que com base nas empresas analisadas, a empresa que se encontra no estágio mais avançado de competitividade de operações de serviço também possui o nível mais alto de maturidade da melhoria contínua (Empresa B); a empresa que se encontra no segundo estágio mais avançado de competividade de operações também possui segundo mais alto nível de maturidade da melhoria contínua (Empresa A); finalmente, a empresa que apresentou o menor estágio de competitividade de operações de serviços, também possui o menor nível de maturidade da melhoria contínua (Empresa C) como pode ser observado na Figura 7. 
Figura 7 - Ilustração da relação entre nível de maturidade da melhoria contínua e competividade em operações de serviços

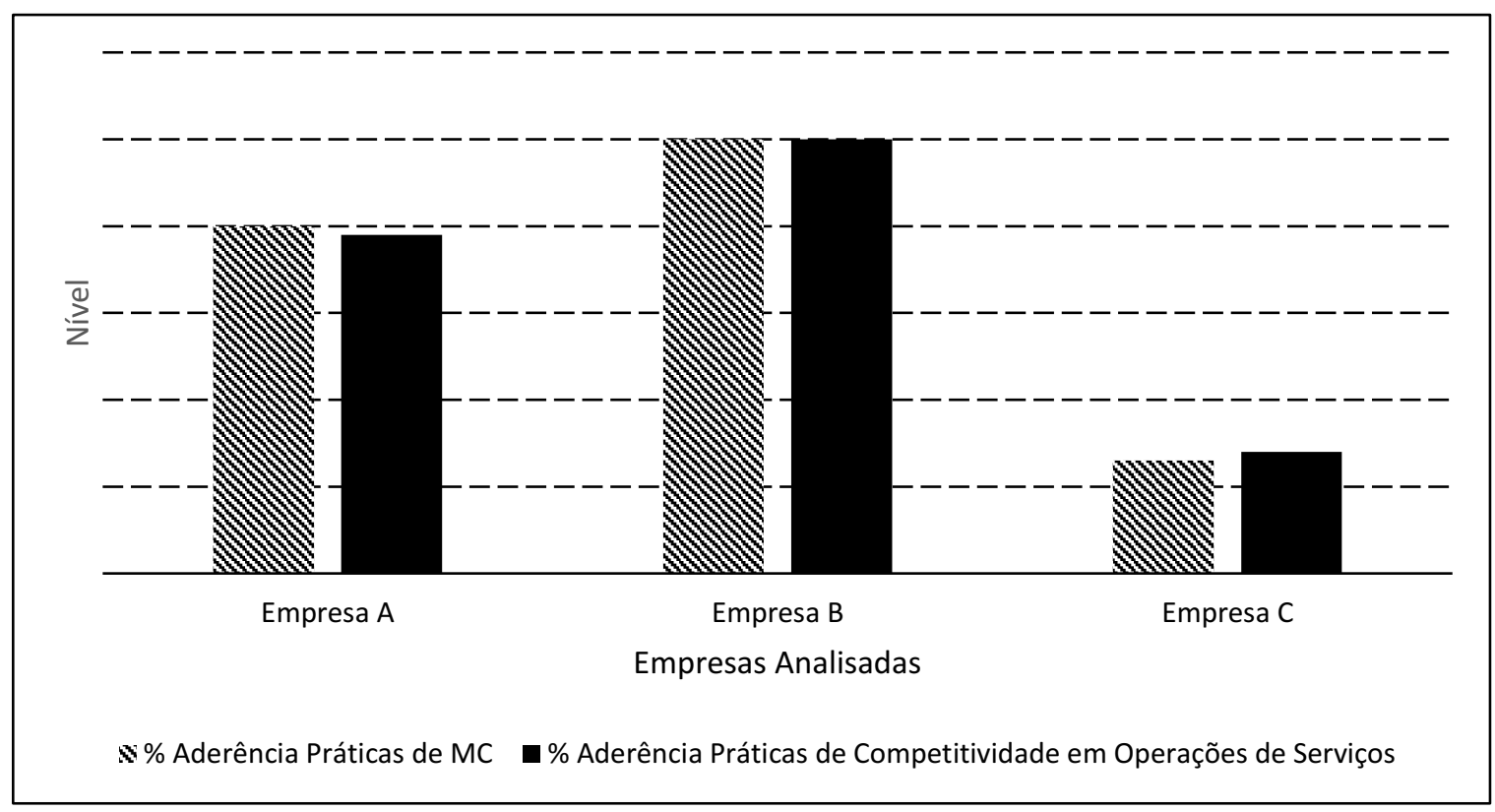

Fonte: Autor, 2017

Com este contexto, é importante reconhecer que o modelo teórico proposto onde elementos da melhoria contínua como, por exemplo, i) propósito do programa - onde se define direção e objetivos da melhoria contínua, balanço entre a melhoria contínua e inovação, ii) processo de melhoria - onde se define a cultura de mudança, estrutura e envolvimento das pessoas, processos e método de melhoria contínua e iii) pessoas - onde se define nível de treinamento realizados junto as pessoas, parecem estar conectados com elementos e práticas esperadas em diferentes estágios da competitividade de operações. Ou seja, é razoável esperar que como o estágio de competitividade de operações de serviços é resultante da evolução de alguns elementos de prática, como, por exemplo, qualidade, back office, cliente, novas tecnologias, pessoas e gestão, é também razoável esperar que o estágio de avanço destes elementos sofra influencias dos níveis de maturidade em que se encontram os elementos e práticas da melhoria contínua.

Embora este estudo não tenha como pretensão descobrir o nível de intensidade com que cada elemento de prática da melhoria contínua se relaciona com os elementos de prática do estágio de competitividade de operações de serviços, é possível observar, através dos casos analisados, que empresas que estão no mais alto estágio de competitividade de operações apresentam alto nível de maturidade nos elementos de prática da melhoria contínua. Esta observação sugere uma possível relação do tipo "causa-efeito" entre nível de maturidade em 
melhoria contínua e estágio de competitividade em operações de serviços, onde empresas com maior nível de maturidade em melhoria contínua devem apresentar maior nível de competitividade em operações. Todavia, para poder afirmar uma relação do tipo "causa-efeito" seria recomendado um estudo mais abrangente com maior número de estudo de casos e também maior compreensão sobre a relação entre as diferentes capacidades observadas pelo modelo de Chase e Hayes (1991) e capacidade de melhoria contínua como variáveis do estágio de competividade em que uma empresa possa estar na medida em que esta desenvolva cada uma destas capacidades.

Com relação as práticas comuns encontradas nas empresas analisadas, o quadro 12 abaixo sintetiza as principais práticas observadas em cada empresa:

Quadro 12 - Síntese das melhores práticas encontradas nos casos analisados

\begin{tabular}{|ll|}
\hline Melhores práticas observadas que contribuem para estágio de competividade de operações de serviços \\
\hline Empresa A & $\begin{array}{l}\text { Possui área de gestão de processos e melhoria contínua } \\
\text { Utiliza metodologia de melhoria contínua (PDCA) } \\
\text { Possui bom nível de formalização e documentação dos processos } \\
\text { Possui governança para monitoramento de indicadores operacionais e resultados } \\
\\
\text { Faz uso de facilitadores e equipes multidisciplinares nos projetos }\end{array}$ \\
\hline Empresa B & $\begin{array}{l}\text { Possui área de gestão de processos e melhoria contínua } \\
\text { Utiliza de metodologia melhoria contínua (Lean Seis Sigma, PDCA, Lean Thinking) }\end{array}$ \\
& $\begin{array}{l}\text { Possui bom nível de formalização e documentação dos processos } \\
\text { Possui governança para monitoramento de indicadores operacionais e resultados } \\
\text { Faz uso de facilitadores e equipes multidisciplinares nos projetos } \\
\text { Programa de melhoria contínua alinhado com programa de formação de líderes }\end{array}$ \\
\hline Empresa C & $\begin{array}{l}\text { Possui área de gestão de processos e melhoria contínua (em implantação) } \\
\text { Possui programa de sugestão de ideias e melhorias }\end{array}$ \\
\hline
\end{tabular}

Fonte: Autor, 2017

Ao observar as práticas encontradas em cada empresa analisada neste estudo de caso, é possível destacar alguns aprendizados sobre a participação de cada uma destas práticas na evolução do estágio de maturidade da melhoria contínua em que se encontra da empresa.

a) todas as empresas analisadas confirmaram a importância de possuir uma área dedicada a gestão da melhoria contínua e processos;

b) empresas A e B que passaram pelos níveis de maturidade melhoria continua estruturada demonstraram ter como base possuir bom nível de formalização e 
documentação de seus processos e utilização de alguma metodologia padrão para melhoria contínua;

c) empresas A e B que passaram pelo nível de maturidade de melhoria contínua orientada para metas demonstraram possuir uma boa governança para acompanhamento dos indicadores operacionais e resultados;

d) empresas A e B que passaram pelo nível de melhoria contínua proativa confirmaram a importância de se fazer uso de facilitadores e equipe multidisciplinar; e;

e) por fim, empresa B, como sendo a única a possuir nível de maturidade capacidade plena em melhoria demonstrou a importância de se utilizar metodologia robustas de melhoria contínua (Lean Seis Sigma, Lean Thinking), alinhamento do programa de melhoria contínua desenvolvimento de líderes.

Finalmente, quando se observa que a adoção de práticas de melhoria contínua pela empresa B é importante para sua competitividade de operações de serviços, contribuindo para seus objetivos de oferecer serviços de excelência e ser líder inovadora, reforça ainda mais a importância de atingir a maturidade de programas de melhoria continua em empresas que buscam também maior competitividade em suas operações de serviços. Por fim, fica evidente a relação entre nível de maturidade de melhoria contínua e estágio de competitividade de operações de serviço em que se encontra cada empresa como pode ser observado na Figura 8. Embora seja razoável esperar que o resultado deste estágio de competitividade não seja uma resultante única do nível de maturidade da melhoria contínua, mas também de outros elementos de práticas já sugeridos por Chase e Hayes (1991) como aqueles apresentados em seu modelo teórico como por exemplo, qualidade de serviços, back office, cliente, inovação tecnologia, força de trabalho e gestão. Adicionalmente, se considerarmos o caso de empresa $\mathrm{C}$, que embora esteja no menor nível de maturidade da melhoria contínua, a mesma empresa se encontra no estágio 2 de competitividade de operações de serviços (profissionalização), sendo, portanto, razoável afirmar que a capacidade de melhoria contínua de cada empresa analisada, se não atuar mais um elemento de prática junto os demais elementos já considerado no modelo de Chase e Hayes (1991), ao menos atua como um facilitador para que a empresa possa evoluir nos demais estágios de competividade de operações de serviços. 
Figura 8 - Matriz relacionamento nível de maturidade da melhoria contínua vs estágio de competitividade de operações de serviços.

\begin{tabular}{|l|l|l|l|l|}
\hline $\begin{array}{l}\text { Estágio 4 - Entrega } \\
\text { com classe mundial }\end{array}$ & & & & Empresa B \\
Estágio 3- \\
Diferencial \\
competitivo \\
alcançado
\end{tabular}

Fonte: Autor, 2017 


\section{CONCLUSÕES}

Este estudo traz como contribuição a proposta de um modelo teórico que busca identificar a relação entre o estágio de competitividade de operações de serviços de uma empresa e o nível de maturidade da melhoria contínua na mesma, ou seja, que elemento de prática da melhoria contínua como i) propósito do programa de melhoria contínua, ii) processo de melhoria contínua e iii) pessoas envolvidas e suportando as iniciativas de melhoria contínua contribuem de alguma forma para os elementos práticos de competitividade de operações em que uma empresa se encontra.

De forma verificar a utilidade deste modelo teórico, foi realizado estudo de caso múltiplo com três empresas onde empresa B foi classificado no mais alto estágio de competitividade (estágio 4- serviço de classe mundial) e também com maior nível de maturidade da melhoria contínua (nível 5 - capacidade plena em melhoria contínua), empresa A foi classificada no segundo estágio mais alto de competitividade (estágio 3 - diferencial competitivo alcançado) e também com segundo maior nível de maturidade da melhoria contínua (nível 3 - melhoria contínua proativa).

O fato de uma empresa estar no maior estágio de competitividade de operações de serviços e também possuir maior nível de maturidade da melhoria continua não sugere necessariamente que determinada empresa no menor nível de maturidade da melhoria contínua deve estar no menor estágio de competitividade. Tal fato foi observado na empresa $\mathrm{C}$ que embora esteja iniciando sua jornada no desenvolvimento da prática de melhoria contínua, a mesma empresa se encontra no estágio 2 de competitividade (profissionalização) o que sugere que a dimensão melhoria contínua possa ser i) uma componente de capacidade adicional ao modelo de 4-estágios de competitividade de Chase ; Hayes (1991) ou eventualmente ii) um catalizador que contribui como um meio para o desenvolvimento entre as demais capacidades deste mesmo modelo que contribui para a evolução ao longo dos diferentes estágio de competitividade de operações de serviços.

Este estudo permitiu melhor compreender os elementos de práticas tanto no que diz respeito a melhoria contínua quanto ao estágio de competitividade de operações de serviços, permitindo, portanto, identificar elementos bases da melhoria contínua que deve ser comum a qualquer empresa que estejam progredindo no estágio de competitividade de operações, como por exemplo i)) alinhamento dos projetos de melhoria contínua com a estratégia da empresa (A3), ii) existência de prática e estrutura de suporte ao programa de melhoria contínua (B1), iii) formalização e padronização de processos (B5) e iv) uso de ferramenta de medição e 
monitoramento dos processos (C5) evidenciando os mesmos como elementos básicos na criação um programa de melhoria contínua independente do seu nível de maturidade.

A realização de estudo também permitiu observar que empresas como empresa B que se encontra no maior estágio de competividade de operações de serviço (estágio 4 - serviço de classe mundial) devem possuir alguns elementos de prática da melhoria contínua como i) o equilíbrio entre melhoria contínua e inovação, e ii) uso da melhoria contínua como um catalizador na formação de talentos e carreira de novos líderes. Isso sugere que alguns elementos específicos da melhoria contínua possam ter um papel fundamento na evolução entre os estágios de competitividade de operações de serviços.

Com isto, o resultado mais importante deste estudo foi identificar, com base nos estudos de casos, existência de relação entre o estágio de competitividade em operações de serviços e o nível de maturidade da melhoria contínua em que se encontra uma empresa, registrando que a empresa B que se encontra no mais alto estágio de competividade de operações (estágio 4 serviço de classe mundial) também possui o maior nível de maturidade da melhoria continua (nível 5 - capacidade plena em melhoria contínua), empresa A que se encontra no segundo estágio mais alto de competitividade de operações (estágio 3 - diferencial competitivo alcançado) também possuir o segundo mais alto nível de maturidade em melhoria contínua (nível 4 - melhoria contínua proativa) e, por fim, a empresa C que se encontra no menor estágio de competitividade de operações de serviços (estágio 2- profissionalização) também possuir o menor nível de maturidade em melhoria contínua (nível 1 - pré melhoria continua).

O modelo teórico proposto foi útil para analisar a relação entre o nível de maturidade da melhoria contínua e o estágio de competitividade de operações de serviços em que se encontram as empresas analisadas e melhor compreender como os elementos de práticas estão presentes nestas empresas considerando seus diferentes níveis de maturidade da melhoria continua e estágio de competitividade de operações de serviços.

Este estudo tem como limitação o alcance de seus resultados seja pelo fato de ter considerado apenas três empresas como parte do estudo de caso, seja pelo fato deste estudo de caso estar inserido apenas na realidade dessas empresas apontando para uma oportunidade de realização de estudos mais avançado para compreender as variáveis que estão associadas ao modelo teórico proposto. Com este objetivo, recomenda-se a realização de futuros estudos para analisar com maiores detalhes como cada variável do modelo teórico se relaciona uma com as outras, uma vez que todos os elementos práticos da melhoria contínua demonstram ser importantes no estágio de competitividade de operações de serviços em que se encontra uma empresa. 


\section{REFERÊNCIAS}

ANAND, G. et al. Dynamic capabilities through continuous improvement infrastructure. Journal of Operations Management, v. 27, n. 2, p. 444 461, 2009. Disponível em:

$<$ http://doi.org/10.1016/j.jom.2009.02.002>. Acesso em: 27 abr. 2017.

BESSANT, J.; CAFFYN, S.; GALLAGHER, M. An evolutionary model of continuous improvement behavior. Technovation, v. 21, n. 2, p. 67-77, 2001. Disponível em:

$<$ http://doi.org/10.1016/S01664972(00)00023-7>. Acesso em: 27 abr. 2017.

BESSANT, J.; CAFFYN, S.; GILBERT, J. Learning to manage innovation. Technohgy Analysis \& Strategic Management, v. 8, n. 1, p. 59-70, 1996. Disponível em:

$<$ http://dx.doi.org/10.1080/09537329608524233>. Acesso em: 27 abr. 2017

BESSANT, J.; FRANCIS, D. Developing strategic continuous improvement capability. International Journal of Operations \& Production Management, v. 19, n. 11, p. 1106-1119, 1999. Disponível em: $<$ http://dx.doi.org/10.1108/01443579910291032>. Acesso em: 27 abr. 2017

BHUIYAN, N.; BAGHEL, A. An overview of continuous improvement: from the past to the present. Management Decision, v. 43, n. 5, p. 761-771, 2005. Disponível em:

$<$ http://dx.doi.org/10.1108/00251740510597761>. Acesso em: 27 abr. 2017

BHUIYAN, N.; BAGHEL, A. WILSON, J. A sustainable continuous improvement methodology at an aerospace company. International Journal of Productivity and Performance Management, v. 55, n. 8, p. 671-687, 2006. Disponível em: <http://dx.doi.org/10.1108/17410400610710206>. Acesso em: 27 abr. 2017

BÍBLIA. A. T. Salmos. In: BÍBLIA. Português. Bíblia sagrada: contendo o antigo e o novo testamento. Tradução de João Ferreira de Almeida. Rio de Janeiro: Sociedade Bíblica do Brasil, p.622-623, 1966

CAFFYN, S. Development of a continuous improvement self-assessment tool. International Journal of Operations \& Production Management, v.19, n.11, p.1138-1153, 1999. Disponível em:

$<$ http://dx.doi.org/10.1108/01443579910291050>. Acesso em: 27 abr. 2017

COLE, R. E. From continuous improvement to continuous innovation. Quality Management Journal, v. 8, n. 4, p. 7-21, 2001. Disponível em: <http://dx.doi.org/10.1080/09544120200000001>. Acesso em: 27 abr. 2017

CHASE R. B.; HAYES R. H. Beefing up operations in service. Sloan Management Review, v. 33, n. 1, 1991. Disponível em:

$<$ http://search.proquest.com/openview/3ddb916a4689d6163f03d797043b7958/1?pqorigsite $=$ gscholar\&cbl $=1817083>$. Acesso em: 27 abr. 2017

CHASE, R. B.; ERIKSON, W. J. The service factory. The Academy of Management Executive, v. 2, n. 3, p. 191-196, 1988. Disponível em: <http://amp.aom.org/content/2/3/191.extract $>$. Acesso em: 27 abr. 2017 
FRYER, K.; OGDEN S.; ANTHONY, J. Bessant's continuous improvement model: revisiting and revising. International Journal of Public Sector Management, v. 26, n. 6, p. 481-494, 2013. Disponível em: <http://dx.doi.org/10.1108/IJPSM-05-2012-0052>. Acesso em: 27 abr. 2017

GOSHAL, S; BARTLETT, C. Linking organizational context and managerial action: the dimensions of quality of management. Strategic Management Journal, v. 15, n. 2, p. 91-112, 1994. Disponível em: $<$ http://dx.doi.org/10.1002/smj.4250151007>. Acesso em: 27 abr. 2017

GIANESI, I. G. N.; CORREAA, H. L. Administração estratégica de serviços. São Paulo: Atlas, 2013.

HALLGREN, M.; OLHAGER, J. Quantification in manufacturing strategy: a methodology and illustration. International Journal of Production Economics, v. 104, n. 1, p. 113-124, 2006. Disponível em: $<$ http://doi.org/10.1016/j.ijpe.2005.09.004>. Acesso em: 27 abr. 2017

HAYES, R.H. \& WHEELWRIGHT, S.C. Restoring our competitive edge: competing through manufacturing. New York: Wiley, 1984

HEUVEL, J. V. D.; DOES, R. J.M.M.; VERVER, J. P.S. Six Sigma in healthcare: lessons learned from a hospital. International Journal Six Sigma and Competitive Advantage, v. 1, n. 4, 2005. Disponível em: $<$ http://dx.doi.org/10.1504/IJSSCA.2005.008504>. Acesso em: 27 abr. 2017

JACKSON, S. Achieving a culture of continuous improvement by adopting the principles of selfassessment and business excellence. International Journal of Health Care Quality Assurance, v.12, n.2, p. 59-64, 1999. Disponível em: <http://dx.doi.org/10.1108/09526869910261277>. Acesso em: 27 abr. 2017

JORGENSEN, F.; BOER, H.; LAUGEN, B. An empirical test of the ci maturity model. Creativity and Innovation Management, v. 15, n. 4, p. 328-337, 2006. Disponível em: $<$ http://dx.doi.org/10.1111/j.1467-8691.2006.00404.x>. Acesso em: 27 abr. 2017

JHA, S.; NOORI, H.; MICHELA, J. L. The dynamics of continuous improvement: aligning organizational attributes and activities or quality and productivity. International Journal of Quality Science, v. 1, n. 1, p. 19-47, 1996. Disponível em: $<$ http://search.proquest.com/openview/ef7f223a151f91ad48e0bb00256b4157/1?pqorigsite $=$ gscholar $\& \mathrm{cbl}=26196>$. Acesso em: 27 abr. 2017

JOHNSTON, R. Operations: from factory to service management. International Journal of Service Industry Management, v. 5, n. 1, p. 49-63, 1994. Disponível em: $<$ http://dx.doi.org/10.1108/09564239410051902>. Acesso em: 27 abr. 2017

LILLIS, B.; SWEENEY, M., Managing the fit between the views of competitive strategy and the strategic role of service operations, European Management Journal, v. 31, n. 6, p. 564-59, 2013. Disponível em: <http://doi.org/10.1016/j.emj.2012.10.001>. Acesso em: 27 abr. 2017

MARTIN C. R.; HORNE, D. A. Restructuring towards a service orientation: the strategic challenges. International Journal of Service Industry Management, v. 3, n. 1, p. 25-38, 1992. Disponível em: $<$ http://dx.doi.org/10.1108/EUM0000000002809>. Acesso em: 27 abr. 2017 
Milner C. D.; SAVAGE, B. M. Modeling continuous improvement evolution in the service sector, International Journal of Quality and Service Sciences, v. 8, n.3, p. 438-460, 2016. Disponível em: $<$ http://dx.doi.org/10.1108/IJQSS-07-2016-0052> Acesso em: 27 abr. 2017

ONA - ORGANIZAÇÃO NACIONAL DE ACREDITAÇÃO. Acreditação. Disponível em: $<$ https://www.ona.org.br/Pagina/33/Acreditacao >. Acesso em: 17. abril. 2017.

PINSONNEAULT, A.; KRAEMER, K. L. Survey research in management information systems: an assessment. Journal of Management Information System, v. 10, n. 2, p. 75-105, 1993. Disponível em: <http://dx.doi.org/10.1080/07421222.1993.11518001>. Acesso em: 27 abr. 2017

PERDOMO-ORTIZ, J.; GONZÁLEZ-BENITO, J.; GALENDE, J. Total quality management as a forerunner of business innovation capability. Technovation, v. 26, p. 1170-1185, 2006. Disponível em: $<$ http://doi.org/10.1016/j.technovation.2005.09.008>. Acesso em: 27 abr. 2017

PRAJOGO, D. I.; SOHAL, A. S. TQM and innovation: a literature review and research framework. Technovation, v. 21, n. 9, p.539-558, 2001. Disponível em: $<$ http://doi.org/10.1016/S01664972(00)00070-5>. Acesso em: 27 abr. 2017

RADNOR, Z. J.; HOLWEG, M., WARING, J. Lean in healthcare: The unfilled promise? Social Science \& Medicine, v. 74, p. 364-371, 2013. Disponível em:

$<$ http://doi.org/10.1016/j.socscimed.2011.02.011>. Acesso em: 27 abr. 2017

SOWER, V.; MOTWANI, J.; SAVOIE, M. Classics in production and operations management. International Journal of Operations \& Production Management, v. 17, n. 1, p. 15-28, 1997. Disponível em: <http://dx.doi.org/10.1108/01443579710157961>. Acesso em: 27 abr. 2017

STEAD, A.; LEONARD, M.C. Changing to a client focused quality service through more effective team work. Health Manpower Management, v. 21, n. 4, p. 23-27, 1995. Disponível em: $<$ http://dx.doi.org/10.1108/09552069510092746>. Acesso em: 27 abr. 2017

SWAMIDASS, P. M., DARLOW, N., BAINES, T. Evolving forms of manufacturing strategy development: evidence and implications. International Journal of Operations \& Production Management, v. 21, n. 10, p. 1289-1304, 2001. Disponível em: $<$ http://dx.doi.org/10.1108/EUM0000000005971>. Acesso em: 27 abr. 2017

TANER, M. T.; SEZEN, B. An overview of six sigma applications in healthcare industry. International Journal of Health Care Quality Assurance, v. 20, n. 4, p. 329-340, 2007. Disponível em: $<$ http://dx.doi.org/10.1108/09526860710754398>. Acesso em: 27 abr. 2017

TRISOLINI, M.G. Applying business management models in health care. International Journal of Health Planning and Management, v. 17: p. 295-314, 2002. Disponível em: $<$ http://dx.doi.org/10.1002/hpm.683>. Acesso em: 27 abr. 2017

VOSS, C. et al. Case research in operations management. International Journal of Operations and Production Management, v. 22, n. 2, p. 195-219, 2002. Disponível em: $<$ http://dx.doi.org/10.1108/01443570210414329>. Acesso em: 27 abr. 2017

YIN, R. K. Estudo de Caso: planejamento e método. 2. ed. São Paulo: Bookman, 2001. 
ZEHIR, C.; SADIKOGLU, E. The relationship between total quality management (TQM) practices and organizational performance: an empirical investigation. International Journal of Production

Economics, v. 127, n. 1, p. 13-26, 2010. Disponível em: <http://doi.org/10.1016/S0272-

6963(03)00004-4>. Acesso em: 27 abr. 2017 
APÊNDICE A - Instrumento de Entrevista e Coleta de Dados 


\section{Protocolo de Entrevista e Coleta de Dados}

Levantamento de campo sobre a maturidade da prática de melhoria continua visando investigar sua relação com a gestão de operações hospitalares.

\section{Instrumento de Coleta de Dados}

\section{Informações:}

Data da visita:

a. Nome da Empresa:

b. Nome do Entrevistado:

c. Cargo:

d. Depto:

e. Tel.: E-mail: (a)

\section{A. Módulo 1 - Maturidade do Programa de Melhoria Contínua}

1. Implantação do programa de melhoria continua

1.1. A empresa utiliza alguma metodologia para melhoria continua ou resolução de problemas? (Se não, vá para a questão 2.2; se sim vá para a questão seguinte) Qual o tipo de metodologia a empresa utiliza:

1.1. Metodologia Lean Six Sigma (consiste na aplicação de metodologia estrutura para solução de problemas em processos existentes cuja causa raiz seja desconhecida aplicando ferramentas estatísticas e conceitos do Lean Manufacturing, como por exemplo DMAIC, Kaizen, Value Stream Map, etc)

1.2. Metodologia de Gestão da Rotina (consiste na aplicação de metodologia para gestão da rotina estrutura para resolução de problemas ou variação nos processos cuja causa raiz seja conhecida aplicando um processo estruturado como por exemplo PDCA, gestão visual, Ishikawa, procedimento padrão.)

1.3. Metodologia de Gestão de Processos de Negócio (consiste na aplicação de metodologia para desenho/modelagem de processo, implantação/revisão de processos, implantação sistema de gestão de performance e monitoramento, capacitação e comunicação do processo aos usuários)

1.4. Metodologia de inovação de processo (consiste na aplicação de metodologia para inovação de produto e serviços através da aplicação de técnicas de inovação como por exemplo Design Thinking.)

1.5. Outras:

\section{Dimensão | Propósito do Programa de MC}

2.1. Como é realizado o processo de definição dos objetivos e metas de negócio e como ocorre seu desdobramento nos demais níveis da organização?

2.2. Como é realizada a comunicação e monitoramento dos objetivos de metas de negócio junto aos colaboradores?

2.3. Como surge um projeto de melhoria contínua na organização?

2.4. Como a organização prioriza os projetos e assegura que estes estejam alinhados com a estratégia do negócio?

2.5. De que forma os recursos de melhoria contínua contribuem para os projetos de desenho de novos processos? 


\section{Dimensão | Processo}

3.1. Como a organização promove o engajamento dos colaboradores de forma que busquem pró-ativamente as oportunidades de mudanças e melhorias nos processos?

3.2. Como ocorre a definição e mobilização da equipe do projeto?

3.3. Qual o nível de formalização dos processos na organização?

3.4. Como a organização promove a padronização dos processos e assegura sua manutenção?

\section{Dimensão | Pessoas}

4.1. Como a organização define os diferentes papeis dos agentes de melhoria contínua?

4.2. Qual a capacidade da organização em treinar os agentes e facilitadores de melhoria contínua?

4.3. Como a organização influencia para que haja o patrocínio do alto nível de gestão nas iniciativas do programa de melhoria contínua?

4.4. Como a organização relaciona o desenvolvimento de carreira de seus colaboradores com o programa de melhoria contínua?

4.5. Como a organização gerencia as lições e aprendizados de cada ciclo de projeto de forma assegurar que o conhecimento seja compartilhado?

4.6. Como a organização utiliza recursos de tecnologia e digitalização ao longo das iniciativas de melhoria contínua?

\section{B. Módulo 2 - Gestão da Operação}

1.1. De forma a organização mensura a qualidade de serviço?

1.2. Como a organização assegura expectativa do cliente esteja sendo atendida?

1.3. Qual o nível da organização em integrar suas operações de suporte ("back office") com operações de atendimento ao cliente ("front office")?

1.4. De que forma a organização busca desenvolver novos serviços e oportunidades de superar expectativa do cliente?

1.5. Como a organização segmenta e gerencia para atender as diferentes expectativas de seus clientes?

1.6. Como a organização aproveita a "Voz do Cliente" no processo de geração de novos serviços e oportunidades?

1.7. De que forma a organização busca e desenvolve novas tecnologia em suas operações?

1.8. Como a organização define e promove o papel do colaborador em relação a expectativa do cliente?

1.9. Qual o papel e atuação dos gestores em relação ao atenaddimento do cliente?

1.10. Qual o papel e atuação dos gestores no desenvolvimento dos colaboradores?

1.11. Informações complementares sobre a operação do hospital:

a) Quadro Total de Colaboradores:

- \% Aprox. em atividades de suporte: $\%$

- \% Aprox. em atividade de atendimento:

b) Tipo de Certificações:

c) Tipos de Serviços Oferecidos pelo site abordado nesta pesquisa: 